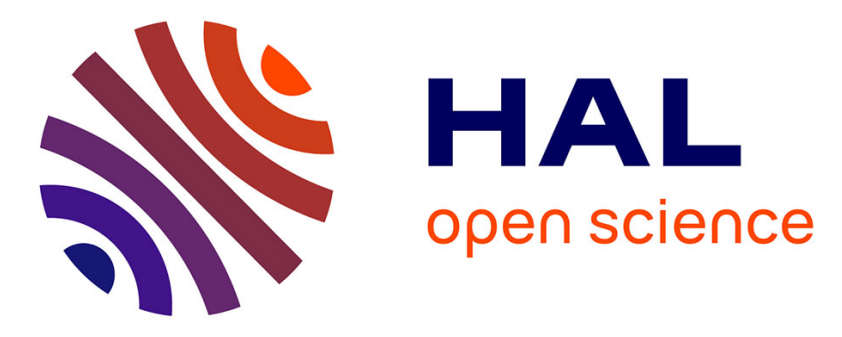

\title{
Nitrogen removal in marine environments: recent findings and future research challenges
}

Stefan Hulth, Robert Curwood Aller, Donald E. Canfield, Tage Dalsgaard, Pia Engström, Franck Gilbert, Kristina Sundbäck, Bo Thamdrup

\section{To cite this version:}

Stefan Hulth, Robert Curwood Aller, Donald E. Canfield, Tage Dalsgaard, Pia Engström, et al.. Nitrogen removal in marine environments: recent findings and future research challenges. Marine Chemistry, 2005, vol. 94, pp. 125-145. 10.1016/j.marchem.2004.07.013 . hal-00780284

\section{HAL Id: hal-00780284 https://hal.science/hal-00780284}

Submitted on 23 Jan 2013

HAL is a multi-disciplinary open access archive for the deposit and dissemination of scientific research documents, whether they are published or not. The documents may come from teaching and research institutions in France or abroad, or from public or private research centers.
L'archive ouverte pluridisciplinaire HAL, est destinée au dépôt et à la diffusion de documents scientifiques de niveau recherche, publiés ou non, émanant des établissements d'enseignement et de recherche français ou étrangers, des laboratoires publics ou privés. 


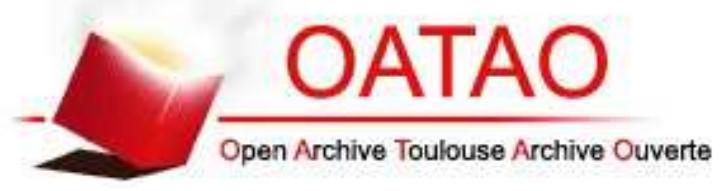

\section{Open Archive Toulouse Archive Ouverte (OATAO)}

OATAO is an open access repository that collects the work of Toulouse researchers and makes it freely available over the web where possible.

This is an author-deposited version published in: http://oatao.univ-toulouse.fr/ Eprints ID: 6098

To link to this article: DOI:

10.1016/j.marchem.2004.07.013

URL: http://dx.doi.org/10.1016/j.marchem.2004.07.013

To cite this version: Hulth, Stefan and Aller, Robert Curwood and Canfield, Donald E. and Dalsgaard, Tage and Engström, Pia and Gilbert, Franck and Sundbäck, Kristina and Thamdrup, Bo Nitrogen removal in marine environments: recent findings and future research challenges. (2005) Marine Chemistry, vol. 94 (n 1-4). pp. 125-145. ISSN 0304-4203

Any correspondence concerning this service should be sent to the repository administrator: staff-oatao@ listes.diff.inp-toulouse.fr 


\title{
Nitrogen removal in marine environments: recent findings and future research challenges
}

\author{
Stefan Hulth ${ }^{\mathrm{a}, *}$, Robert C. Aller ${ }^{\mathrm{b}}$, Donald E. Canfield ${ }^{\mathrm{c}}$, Tage Dalsgaard ${ }^{\mathrm{d}}$ Pia Engström $^{\mathrm{a}}$, \\ Franck Gilbert ${ }^{\mathrm{e}}$, Kristina Sundbäck ${ }^{\mathrm{f}}$, Bo Thamdrup ${ }^{\mathrm{c}}$ \\ ${ }^{a}$ Department of Chemistry, Göteborg University, SE-412 96 Göteborg, Sweden \\ ${ }^{\mathrm{b}}$ Marine Sciences Research Center, State University of New York at Stony Brook, Stony Brook, New York 11794-5000, USA \\ ${ }^{\mathrm{c}}$ Danish Center for Earth System Science, Institute of Biology, University of Southern Denmark, DK-5230 Odense M, Denmark \\ ${ }^{\mathrm{d}}$ Department of Marine Ecology, National Environmental Research Institute, Vejlsøvej 25, DK-8600 Silkeborg, Denmark \\ ${ }^{\mathrm{e}}$ Laboratoire de Microbiologie, Géochimie et Ecologie Marines (COM), UMR CNRS 6117, Faculté de Luminy, \\ Case 901, F-13288 Marseille Cedex 9, France \\ ${ }_{\mathrm{f}}^{\mathrm{f}}$ Department of Marine Ecology, Marine Botany, Göteborg University, Box 461; SE-405 30 Göteborg, Sweden
}

\begin{abstract}
Respiratory reduction of nitrate (denitrification) is recognized as the most important process converting biologically available (fixed) nitrogen to $\mathrm{N}_{2}$. In current $\mathrm{N}$ cycle models, a major proportion of global marine denitrification (50-70\%) is assumed to take place on the sea floor, particularly in organic rich continental margin sediments. Recent observations indicate that present conceptual views of denitrification and pathways of nitrate reduction and $\mathrm{N}_{2}$ formation are incomplete. Alternative $\mathrm{N}$ cycle pathways, particularly in sediments, include anaerobic ammonium oxidation to nitrite, nitrate and $\mathrm{N}_{2}$ by $\mathrm{Mn}$-oxides, and anaerobic ammonium oxidation coupled to nitrite reduction and subsequent $\mathrm{N}_{2}$ mobilization. The discovery of new links and feedback mechanisms between the redox cycles of, e.g., C, N, S, Mn and Fe casts doubt on the present general understanding of the global $\mathrm{N}$ cycle. Recent models of the oceanic $\mathrm{N}$ budget indicate that total inputs are significantly smaller than estimated fixed $\mathrm{N}$ removal. The occurrence of alternative $\mathrm{N}$ reaction pathways further exacerbates the apparent imbalance as they introduce additional routes of $\mathrm{N}$ removal. In this contribution, we give a brief historical background of the conceptual understanding of $\mathrm{N}$ cycling in marine ecosystems, emphasizing pathways of aerobic and anaerobic $\mathrm{N}$ mineralization in marine sediments, and the implications of recently recognized metabolic pathways for $\mathrm{N}$ removal in marine environments.
\end{abstract}

\footnotetext{
* Corresponding author. Tel.: +46 3177222770; fax: +46 317722785 .

E-mail address: stefan.hulth@chem.gu.se (S. Hulth).
} 


\section{Introduction}

Nitrogen occurs in a multiplicity of forms and oxidation states, with organic and inorganic compounds that exhibit a wide range of reaction/transformation/transport pathways in the biosphere (Carpenter and Capone, 1983; Kirchman, 2000a; Table 1). It is a constituent of vital importance for life on Earth, as all organisms, regardless of physiology, require $\mathrm{N}$ for growth and fix it in relatively consistent stoichiometric proportion to $\mathrm{C}$ and other essential elements (Redfield, 1958). Also, forms of N are directly involved in the energetic metabolism of certain heterotrophic and autotrophic bacteria (Jørgensen and Gallardo, 1999; Seitzinger, 1988; Zehr and Ward, 2002). Since the early 20th century, patterns and quantities of nitrogen discharged to the environment have changed dramatically, largely associated with increasing human activities and technical advancements (e.g., Herbert, 1999; Vitousek et al., 1997). Although changes are most evident on a regional scale, the global cycle of nitrogen has been altered by human activities to a greater extent than most other bioactive elements. Anthropogenic perturbations that affect the balance between recalcitrant and dynamic/bioavailable $\mathrm{N}$ include industrial production of nitrogen fertilizers and agricultural discharge, $\mathrm{NO}_{x}$ emissions from combustion engines and biomass burning, industrial and domestic sewage effluents, and the cultivation of legumes (Herbert, 1999; Vitousek et al., 1997). Important incentives for a better understanding of global $\mathrm{N}$ cycling have derived from feedbacks in the overall dynamics of

Table 1

Nitrogen-containing compounds can be found in a multiplicity of forms at a wide range of oxidation states in marine environments

\begin{tabular}{lll}
\hline Compound & & Oxidation state \\
\hline Nitrate & $\mathrm{NO}_{3}^{-}$ & $+\mathrm{V}$ \\
Nitrogen dioxide & $\mathrm{NO}_{2}$ & $+\mathrm{IV}$ \\
Nitrite & $\mathrm{NO}_{2}^{-}$ & $+\mathrm{III}$ \\
Nitric oxide & $\mathrm{NO}$ & $+\mathrm{II}$ \\
Nitrous oxide & $\mathrm{N}_{2} \mathrm{O}$ & $+\mathrm{I}$ \\
Di nitrogen & $\mathrm{N}_{2}$ & 0 \\
Hydroxylamine & $\mathrm{NH}_{2} \mathrm{OH}$ & $-\mathrm{I}$ \\
Hydrazine & $\mathrm{N}_{2} \mathrm{H}_{4}$ & $-\mathrm{II}$ \\
Ammonium & $\mathrm{NH}_{4}^{+}$ & $-\mathrm{III}$ \\
Amino acids & $\mathrm{R}_{-} \mathrm{NH}_{2}$ & $-\mathrm{III}$ \\
Urea & $\mathrm{NH}_{2} \mathrm{CONH}_{2}$ & $-\mathrm{III}$ \\
\hline
\end{tabular}

global climate, the depletion of the atmospheric ozone layer, and the anthropogenic inputs of $\mathrm{N}$ to aquatic environments (Crutzen, 1970; Falkowski, 1997; Falkowski et al., 1998; Vitousek et al., 1997).

In most areas of the ocean, the extent and duration of phytoplankton production is constrained by the availability of essential plant macronutrients, of which nitrogen (mainly $\mathrm{NO}_{3}^{-}$and $\mathrm{NH}_{4}^{+}$, but also urea, amino acids and shorter peptides) is often considered limiting (e.g., Antia et al., 1991; Dugdale, 1967; Dugdale and Goering, 1967; Eppley et al., 1979; Howarth, 1988; McCarthy and Carpenter, 1983; Ryther and Dunstan, 1971). Thus, the global nitrogen cycle often modulates the short-term sequestration of atmospheric carbon dioxide into marine phytoplankton, and the export of carbon and associated elements from oceanic surface waters (e.g., Carpenter and Capone, 1983; Falkowski et al., 1998). There are also indications from the geological record that key processes of the $\mathrm{N}$ cycle covary with marine primary production and with climate change (McElroy, 1983). The marine cycles of $\mathrm{C}, \mathrm{N}, \mathrm{P}$ and $\mathrm{O}_{2}$ are apparently inextricably linked by a set of feedbacks, some of which are most likely important also in the history of the Earth and evolution of life (e.g., Anbar and Knoll, 2002; Bjerrum and Canfield, 2002; Falkowski, 1997). In modern marine environments we also observe complex links between $\mathrm{N}$ redox transformations and, e.g., S, Mn, Fe, and I redox cycles (e.g., Aller and Rude, 1988; Aller et al., 1998; Anschutz et al., 2000; Bjerrum and Canfield, 2002; Hulth et al., 1999; Lovley, 2000; Luther et al., 1997; Murray et al., 1995; Straub et al., 1996; Ullman and Aller, 1985).

The marine nitrogen cycle sets itself apart from the cycles of other macronutrients as some marine organisms can alter the redox state of $\mathrm{N}$ and thereby directly add or remove available $\mathrm{N}$ from the oceanic pool. These transformations can also promote exchange between global N-reservoirs, such as the atmosphere and sediments (Carpenter and Capone, 1983; Kirchman, 2000a). Denitrification, a dissimilatory process in which nitrate rather than oxygen is used as electron acceptor by microorganisms, is generally acknowledged as the main sink for available $\mathrm{N}$ in marine environments (e.g., Seitzinger, 1988). In denitrification, dissolved $\mathrm{NO}_{3}^{-}$is reduced to $\mathrm{N}_{2}$ gas through a series of intermediates $\left(\mathrm{NO}_{2}^{-}, \mathrm{NO}\right.$, and $\mathrm{N}_{2} \mathrm{O}$ ) (Knowles, 1982). As most marine organisms 
that require nitrogen for nutrition cannot assimilate either $\mathrm{N}_{2} \mathrm{O}$ or $\mathrm{N}_{2}$, denitrification generally results in a net loss of $\mathrm{N}$ from the system. This sink of fixed $\mathrm{N}$ is at least partly balanced by $\mathrm{N}_{2}$ fixation, an assimilatory process where $\mathrm{N}_{2}$ gas is reduced to biologically available $\mathrm{NH}_{4}^{+}$by a wide variety of prokaryotes (e.g., marine cyanobacteria; Postgate, 1982; Young, 1992). The transformation of $\mathrm{N}_{2}$ to proteinaceous $\mathrm{N}$ and other organic $\mathrm{N}$ compounds (e.g., nucleic acids) results in the addition of new available nitrogen to the ocean.

During the last decades, the discovery of new links between biogeochemically important constituents and novel routes during $\mathrm{N}$ mineralization has challenged our understanding of the marine $\mathrm{N}$ cycle. Furthermore, most oceanic $\mathrm{N}$ models suggest that sources (e.g., riverine- and atmospheric input, bacterial and anthropogenic $\mathrm{N}$-fixation) and sinks (e.g., burial in sediments and denitrification) are out of balance (Codispoti, 1995; Codispoti et al., 2001; Middelburg et al., 1996). According to recent revisions, total inputs appear significantly (on the order of 100-200 $\mathrm{Tg} \mathrm{N}$ year ${ }^{-1} ; T=10^{12}$ ) smaller than estimates of nitrogen removal (Capone, 2000; Codispoti et al., 2001). Findings of additional, alternative $\mathrm{N}$ reaction pathways seem to further exacerbate the imbalance as they introduce additional routes of $\mathrm{N}$ removal. For example, there are indications that previously unknown mechanisms of anaerobic ammonium oxidation to either nitrite/nitrate (prerequisites for denitrification) or $\mathrm{N}_{2}$ may be significant for $\mathrm{N}$ cycling and $\mathrm{N}$ removal in some environments (Dalsgaard et al., 2003; Engström et al., 2004; Hulth et al., 1999; Kuypers et al., 2003; Luther et al., 1997; Thamdrup and Dalsgaard, 2002; Ward, 2003). Apparently, while we seem to understand most key processes of the $\mathrm{N}$ cycle relating to $\mathrm{C}$ dynamics, and their temporal and spatial variability in the ocean, our knowledge still remains rudimentary with respect to the quantitative controls and feedbacks for these alternative routes of marine $\mathrm{N}$ cycling.

Although there are a number of excellent reviews on the biogeochemistry of $\mathrm{N}$ in marine environments (e.g., Blackburn, 1983; Carpenter and Capone, 1983; Christensen et al., 1987; Codispoti et al., 2001; Herbert, 1999; Koike and Sørensen, 1988; Pearl and Zehr, 2000; Postgate, 1982; Seitzinger, 1988; Ward, 2000; Zehr and Ward, 2002), the continuous discov- ery of previously unexplored reaction and transformation pathways needs to be acknowledged and incorporated into conceptual models of global $\mathrm{N}$ cycles and into future study designs. Here, in addition to an introductory review on the evolution of $\mathrm{N}$ species during the history of Earth, we summarize current knowledge on alternative pathways of $\mathrm{N}$ removal from marine ecosystems, and provide examples on challenges for future research on $\mathrm{N}$ cycling in marine environments.

\section{On the evolution of nitrogen species}

During Earth's history, the chemistry of the oceans and atmosphere has undergone dramatic changes driven mainly by the interactions of evolving biological activity and geological processes. Perhaps, most notably and as a direct result of the feedback mechanisms that operate between photosynthesis and burial of organic $\mathrm{C}$ and other reduced substances in sediments, molecular oxygen now constitutes $21 \%$ of the atmosphere and is present in $>99 \%$ of the ocean volume (Codispoti et al., 2001). Free oxygen was virtually absent at the surface of the early Earth (e.g., Holland, 1994; Kasting, 1993). Owing to the redoxdependent properties of $\mathrm{N}$ speciation, overall $\mathrm{N}$ characteristics and speciation between compounds have been significantly modified in response to this photosynthetic oxidation. General constraints of the $\mathrm{N}$ cycle may indeed themselves have affected biogeochemical evolution (Anbar and Knoll, 2002; Falkowski, 1997).

At least since the beginning of the Archean at 3.8 $\mathrm{Ga}$ (billion years ago), atmospheric $\mathrm{N}_{2}$ has been the most abundant form of $\mathrm{N}$ (Kasting, 1990, 1993). Primordial volcanism may have been a source of ammonia $\left(\mathrm{NH}_{3}\right)$, and prebiotic synthesis may have accumulated $\mathrm{N}$-containing organic compounds in the oceans. These were, however, likely depleted soon after the origin and proliferation of life (Falkowski, 1997). Abiotic N fixation could occur at high temperatures generated by, e.g., electric discharge (Kasting, 1990; Yung and McElroy, 1979), with rates and pathways dependent on the composition and oxidation capacity of the atmosphere. In an early $\mathrm{CO}_{2}-\mathrm{N}_{2}$ atmosphere, nitric oxide (NO) would be the main product (Kasting and Walker, 1981; Navarro- 
González et al., 2001), a fraction of which would disproportionate in seawater to $\mathrm{N}_{2} \mathrm{O}, \mathrm{NO}_{2}^{-}$and $\mathrm{NO}_{3}^{-}$ (Kasting and Siefert, 2001). These potential nutrient species could either be assimilated or recycled to $\mathrm{N}_{2}$ through biogenic denitrification, if this process had evolved, or through abiogenic chemo-denitrification (e.g., Ottley et al., 1997). A NO production some $10^{3}$ times less than the rate of biological $\mathrm{N}$ fixation in the modern ocean (see below) has been estimated for an Archean atmosphere, suggesting that the earliest life forms were subject to a strong selective pressure towards the evolution of diazotrophy ( $\mathrm{N}_{2}$ fixation; Navarro-González et al., 2001).

Low sulfate concentrations in the Archean ocean are thought to have favoured methanogenesis, likely resulting in high atmospheric methane concentrations (Habicht et al., 2002). In such an atmosphere, $\mathrm{N}$ may be fixed as hydrogen cyanide $(\mathrm{HCN})$, which may under the appropriate conditions hydrolyse in solution producing $\mathrm{NH}_{3} / \mathrm{NH}_{4}^{+}$(Kasting and Siefert, 2001; Zahnle, 1986). Moderate rises in $\mathrm{O}_{2}$ and oceanic $\mathrm{SO}_{4}^{2-}$ levels in the Paleoproteozoic at 2.4-2 Ga would progressively have inhibited methanogenesis and depleted atmospheric $\mathrm{CH}_{4}$, thus shutting down this fixed N source (Habicht et al., 2002; Kasting et al., 2001).

Fixation of $\mathrm{N}_{2}$ is found in both Bacteria and Archaea (Young, 1992), and likely originated before the separation of these domains (Braun et al., 1999; Fani et al., 2000). Plausibly, prokaryotic diversification occurred already in the early Archean (Schidlowski, 1988; Shen et al., 2001). Diazotrophy may thus have been the main source of fixed $\mathrm{N}$ at that time (Falkowski, 1997). In the absence of $\mathrm{O}_{2}$, no $\mathrm{N}$ is lost through coupled nitrification-denitrification, the dominating $\mathrm{N}$ sink of today (Seitzinger, 1988). Abiotically fixed $\mathrm{NO}_{3}^{-}$and $\mathrm{NO}_{2}^{-}$may have supported anaerobic ammonium oxidation (the anammox reaction) producing $\mathrm{N}_{2}$ at low relative rates (Mulder et al., 1995; Van de Graaf et al., 1995; see below). Additionally, photooxidation may have generated small amounts of Mn-oxides (Anbar and Holland, 1992), which could also potentially serve as an oxidant for $\mathrm{NH}_{4}^{+}$to either $\mathrm{NO}_{2}^{-}, \mathrm{NO}_{3}^{-}$, or $\mathrm{N}_{2}$ (Hulth et al., 1999; Luther et al., 1997; see below) and thereby contribute to the removal of fixed N. However, the generation of substantial amounts of any of these oxidants ultimately depends on $\mathrm{O}_{2}$. Thus, once $\mathrm{N}$ fixation had evolved in the anoxic Archean, this process may have fully relieved any $\mathrm{N}$ limitation, leaving phosphate as the likely limiting nutrient in the Archean ocean (Bjerrum and Canfield, 2002).

During the Paleoproterozoic era, a major biogeochemical transition appears to have transformed a ferrous iron-rich ocean, with only sporadic occurrences of $\mathrm{O}_{2}$, to sulfidic waters underlying a surface layer with moderate $\mathrm{O}_{2}$ concentrations (Anbar and Knoll, 2002; Canfield, 1998). This increase in $\mathrm{O}_{2}$ may have stimulated the evolution and proliferation of nitrifying bacteria, and thereby initiated the first substantial production of oxidized forms of $\mathrm{N}$ such as $\mathrm{NO}_{2}^{-}$and $\mathrm{NO}_{3}^{-}$in the surface waters of the ocean. The occurrence of these species would in turn support the existence of bacteria for denitrification, and thereby open for processes that today dominate $\mathrm{N}$ removal in the ocean (Falkowski, 1997). Concurrently, the $\mathrm{Fe}$ - and Mo-dependent processes of $\mathrm{N}$ fixation and $\mathrm{NO}_{3}^{-}$assimilation may have been suppressed due to severe scavenging of these elements in the sulfidic deep waters (Anbar and Knoll, 2002). The limitation of sources and a pronounced importance of sinks for fixed $\mathrm{N}$ may have lead to substantial $\mathrm{N}$ limitation of primary production during the Mesoproterozoic era, at $\sim 1.2-1.8 \mathrm{Ga}$, possibly hindering the diversification of eukaryotic algae (Anbar and Knoll, 2002).

A second major biogeochemical transition from sulfidic to oxic deep water has been dated to the Neoproterozoic at $\sim 0.8-0.6$ Ga (Canfield and Teske, 1996). After this change, $\mathrm{NO}_{3}^{-}$rather than $\mathrm{NH}_{4}^{+}$ became the most abundant form of inorganic $\mathrm{N}$, and the marine $\mathrm{N}$ cycle may have operated in a manner similar to the present.

\section{Classical view of nitrogen removal during mineralization}

Perhaps the most striking property of nitrogen is that it is found in a wide range of oxidation states, from - III ( $\mathrm{NH}_{4}^{+}$and organic tissues) to $+\mathrm{V}\left(\mathrm{NO}_{3}^{-}\right.$; Table 1). Most redox transformations of organic and inorganic $\mathrm{N}$ species are a consequence of the activities of microscopic organisms, such as unicellular algae and bacteria, during biomass synthesis and organic matter mineralization (Fig. 1). Inorganic 


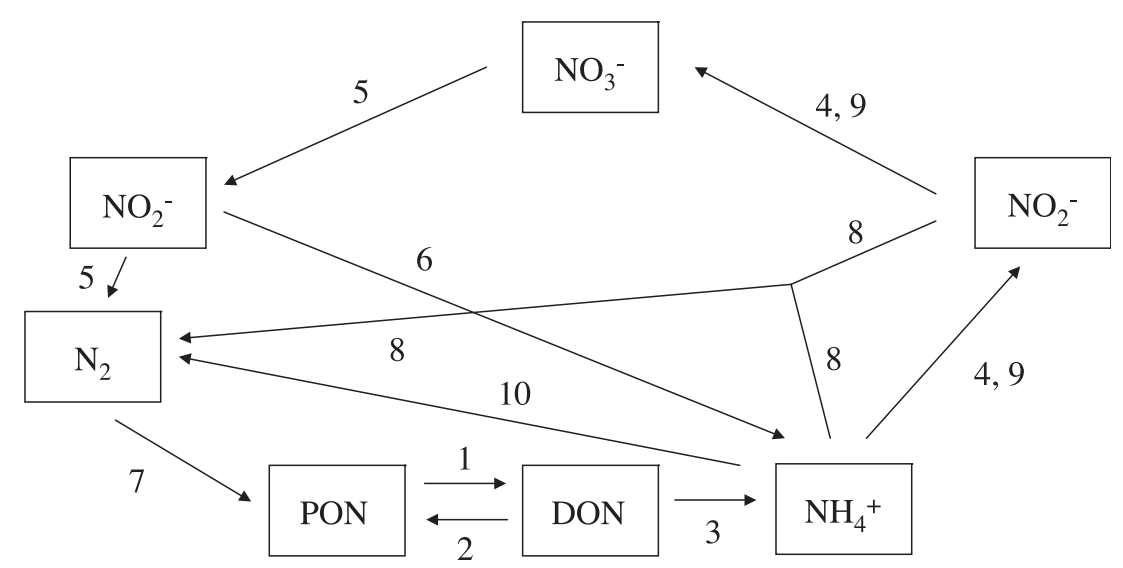

Fig. 1. General view of the complex web of reactions transforming nitrogen compounds of a wide range of forms and oxidation states in the oceans. Indicated are hydrolysis of complex polymers to monomeric or oligomeric units (1), biological incorporation of inorganic and organic forms of $\mathrm{N}$ (2), deamination and mobilization of ammonium following heterotrophic metabolism (ammonification) (3), aerobic nitrification (4), denitrification (5), dissimilatory nitrate/nitrite reduction to ammonium (6), nitrogen fixation (7), anaerobic ammonium oxidation by nitrite (anammox) (8), and anaerobic ammonium oxidation to nitrite and nitrate (9), or $\mathrm{N}_{2}(10)$.

and organic (mainly urea, amino acids and shorter peptides) forms of $\mathrm{N}$ are incorporated into a variety of photosynthetic microbes (Antia et al., 1991). For incorporation, the oxidized forms of $\mathrm{N}$ must first be reduced to organic $\mathrm{N}$ or $\mathrm{NH}_{4}^{+}$by assimilatory $\mathrm{NO}_{3}^{-}$ and $\mathrm{NO}_{2}^{-}$reductase (e.g., Falkowski, 1983; Kirchman, 2000b). Ammonium contains nitrogen at the oxidation levels of amino acids and proteins, and is generally therefore the primary nitrogen source assimilated by both phytoplankton and bacteria. Nitrogen fixation, the assimilatory reduction of $\mathrm{N}_{2}$, also produces biologically available or proteinaceous N (Carpenter, 1983; Howarth and Marino, 1988; Postgate, 1982).

Nitrogen is mineralized during the degradation of nitrogen-containing organic macromolecules such as proteins, polypeptides, dissolved free and dissolved combined amino acids. Mineralization products include ammonium, which may subsequently be oxidized through nitrification to nitrite and nitrate (Figs. 1 and 2). Nitrate and nitrite have the potential to be used as electron acceptors, preferentially when oxygen concentrations are low or in anoxic environments. Denitrification, the reduction of more oxidized forms of nitrogen, i.e., $\mathrm{NO}_{3}^{-}, \mathrm{NO}_{2}^{-}, \mathrm{NO}$ and $\mathrm{N}_{2} \mathrm{O}$ to $\mathrm{N}_{2}$, is generally coupled to the oxidation of reduced $\mathrm{C}$, $\mathrm{Fe}$ and S species (Jørgensen and Gallardo, 1999; Knowles, 1982; Payne, 1976; Seitzinger, 1988; Straub et al., 1996; Zumft, 1997). Enzymes of denitrification are inhibited in the presence of oxygen, and recent investigations indicate inhibition at oxygen concentrations of only a few micromolar (Codispoti et al., 2001). Thus, denitrification is restricted to anoxic or nearly anoxic sediment horizons and anoxic/suboxic waters such as the Black Sea, the Cariaco Basin and the oxygen minimum zones of the eastern Tropical Pacific and the Arabian Sea (Codispoti et al., 2001). In contrast to the observations made in natural environments, aerobic denitrification has been reported in, e.g., batch cultures (Robertson et al., 1995). Such findings imply that inhibition of denitrification by $\mathrm{O}_{2}$ may not always be effective. The regulation of nitrification and denitrification in marine sediments, and their coupling, is complex due to the involvement of both aerobic and anaerobic processes, catalyzed by a wide suite of bacteria.

Denitrification is generally considered the major process removing nitrogen from the oceans (Christensen et al., 1987; Christensen, 1994; Devol, 1991; Seitzinger, 1988). Overall, denitrification is most important in organic rich sediments deposited on the shelf, slope and rise of continental margins throughout the world's oceans. This is where $50-70 \%$ of marine denitrification occurs (e.g., Codispoti et al., 2001; Gruber and Sarmiento, 1997). The general concept of coupled benthic nitrification/denitrification is usually assumed to follow a strict sequence of vertically stratified diagenetic reactions with nitrification in the oxic portion of the sediment, and denitrification just below in the suboxic or anoxic sediment layer (Fig. 2; 


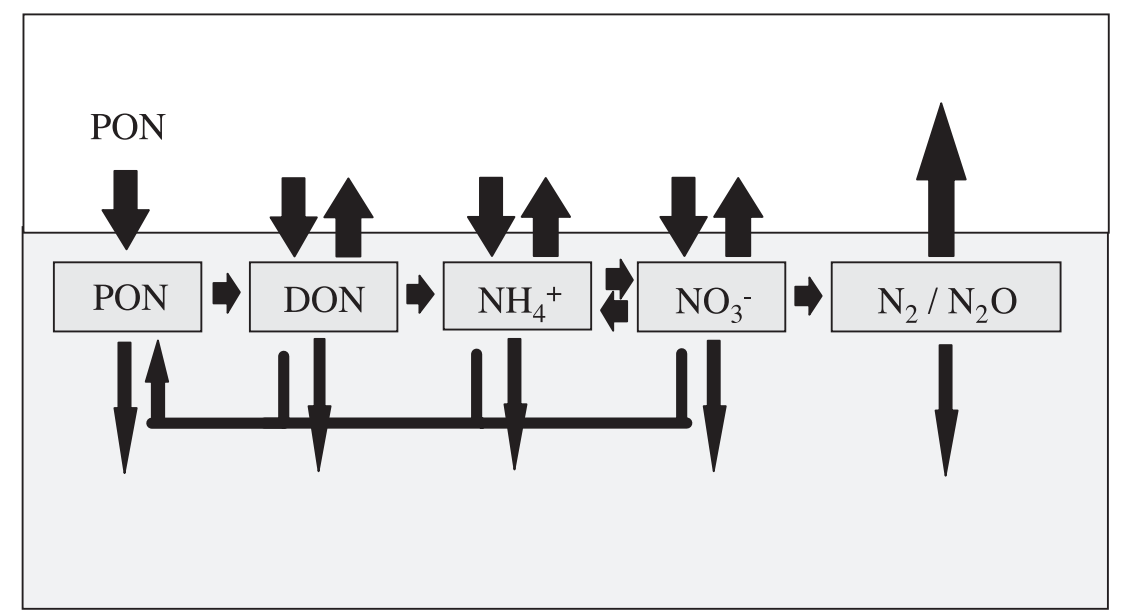

Fig. 2. Schematic representation of the classical view of the major transformation pathways during nitrogen cycling in marine sediments. The illustration includes sedimentation and burial of particulate organic nitrogen (PON), hydrolysis of PON, ammonification, nitrification and denitrification, benthic fluxes of $\mathrm{N}$ containing organic and inorganic solutes, adsorption and microbial incorporation of ammonium, dissimilatory reduction of nitrite/nitrate (nitrite/nitrate ammonification), microbial incorporation of nitrate, and diffusion of $\mathrm{N}$ solutes from the zone of mobilization to deeper sediment layers.

Henriksen and Kemp, 1988). According to this classical view, coupled nitrification/denitrification is constrained by the diffusive or advective transport of nitrate from oxic to anoxic zones in the sediment. Even though the two processes seem mutually exclusive with respect to $\mathrm{O}_{2}$ requirements, the often sharp gradients of $\mathrm{O}_{2}, \mathrm{NH}_{4}^{+}$, and $\mathrm{NO}_{3}^{-}$in surface sediments allow them to operate in close proximity to each other. Moreover, while requiring oxygen for ammonium oxidation and for respiration, nitrifying bacteria are considered to thrive best under relatively low oxygen conditions (Goreau et al., 1980). The zone in which nitrification occurs may be less than 1$\mathrm{mm}$ thick, or extend over several centimeters, mainly depending on the physical regime and rates of organic matter supply to the sediment (Billen, 1982; Christensen and Rowe, 1984). In sediments with high rates of organic supply, oxygen consumption rates are generally high and oxygen penetration is narrow. In such environments, additional nitrate is typically obtained from the overlying water (e.g., Koike and Sørensen, 1988). Nielsen (1992) described a versatile method utilizing a ${ }^{15} \mathrm{~N}-\mathrm{NO}_{3}^{-}$tracer that allows denitrification based on either of the two nitrate sources $\left(D_{n}\right.$ and $\left.D_{w}\right)$ to be measured simultaneously. While denitrification coupled to nitrification in the surface sediment $\left(D_{n}\right)$ depends on ammonium and oxygen concentrations in the zone of nitrification (Gilbert et al., 2003), denitrification of water column nitrate $\left(D_{w}\right)$ is governed by nitrate concentrations in the overlying water and negatively correlated to oxygen availability (Henriksen and Kemp, 1988).

In addition to denitrification, a diverse assembly of prokaryotes couple the oxidation of organic $\mathrm{C}$ or reduced $\mathrm{Fe}$ and $\mathrm{S}$ to the reduction of nitrate via nitrite to ammonium (Blackburn, 1983; Jørgensen and Gallardo, 1999; Figs. 1 and 2). This process (sometimes referred to as dissimilatory nitrite reduction to ammonium, or nitrate/nitrite ammonification) appears (at least) as important as denitrification for total $\mathrm{NO}_{3}^{-}$ reduction in environments with high rates of carbon mineralization, e.g., fish farm sediments (Christensen et al., 2000; Gilbert et al., 1997; Hattori, 1983). Also, sediment-water incubations of intact cores with highly reducing and laminated sediments from the Baltic Sea indicated that only less than $5 \%$ of the nitrate flux $\left(0.81-1.3 \mathrm{mmol} \mathrm{NO}_{3}^{-} \mathrm{m}^{-2}\right.$ day $\left.^{-1} ; n=20\right)$ into the sediment was due to denitrification (Karlsson et al., pers. comm.). Generally, however, nitrite reduction to ammonium is considered less important for $\mathrm{NO}_{3}^{-} / \mathrm{NO}_{2}^{-}$removal in marine sediments with low to moderate organic loading (Binnerup et al., 1992). Due to the comparably few studies that directly measure the dissimilative reduction of $\mathrm{NO}_{2}^{-}$to $\mathrm{NH}_{4}^{+}$, at least in direct combination with measurements of denitrification, the importance of this process for overall $\mathrm{N}$ cycling in coastal marine sediments is unclear. 


\section{Alternative pathways during nitrogen removal}

A long-standing paradigm in aquatic biogeochemistry is that there is a preferential use of electron acceptors yielding the most profitable amount of energy during the oxidation of organic matter. This, in turn, results in a well-defined vertical zonation of solutes (Froelich et al., 1979). During the last decades, however, there are a number of laboratory and field observations indicating that the sequential patterns of mineralization, and the relative vertical stratification of reactants, are a simplification of biogeochemical processes taking place during early diagenesis of organic matter (Figs. 1 and 3). In the following sections we present some of the recent discoveries that have challenged the overall conceptual understanding of nitrogen mineralization in marine environments. Through these novel metabolic pathways, the formation of $\mathrm{N}_{2}$ could potentially be more efficient and straightforward compared to the classic reaction schemes during aerobic nitrification/ anaerobic denitrification.

\subsection{Links between nitrogen removal and the Mn and Fe redox cycles}

During the last two decades, there have been significant advances in the overall understanding of processes utilizing $\mathrm{Fe}$ - and Mn-oxides as electron acceptors during organic matter mineralization (e.g., Canfield et al., 1993b; Lovley, 1991, 1993; Lovley and Phillips, 1986; Nealson and Saffarini, 1994; Thamdrup, 2000). Overall, a significant fraction of anaerobic organic carbon mineralization in marine sediments is due to $\mathrm{Mn}$ - and $\mathrm{Fe}$ reducing microorganisms (e.g., Canfield et al., 1993a,b; Burdige, 1993; Thamdrup, 2000). Although denitrification is a relatively well-studied process (e.g., Lipschultz et al., 1990), the bacterially mediated aerobic nitrification/anaerobic denitrification process does not leave out alternative and less known pathways from the formation of $\mathrm{N}_{2}$. Coupled nitrogen and metal redox reactions constitute important examples of such novel routes during $\mathrm{N}$ mineralization.

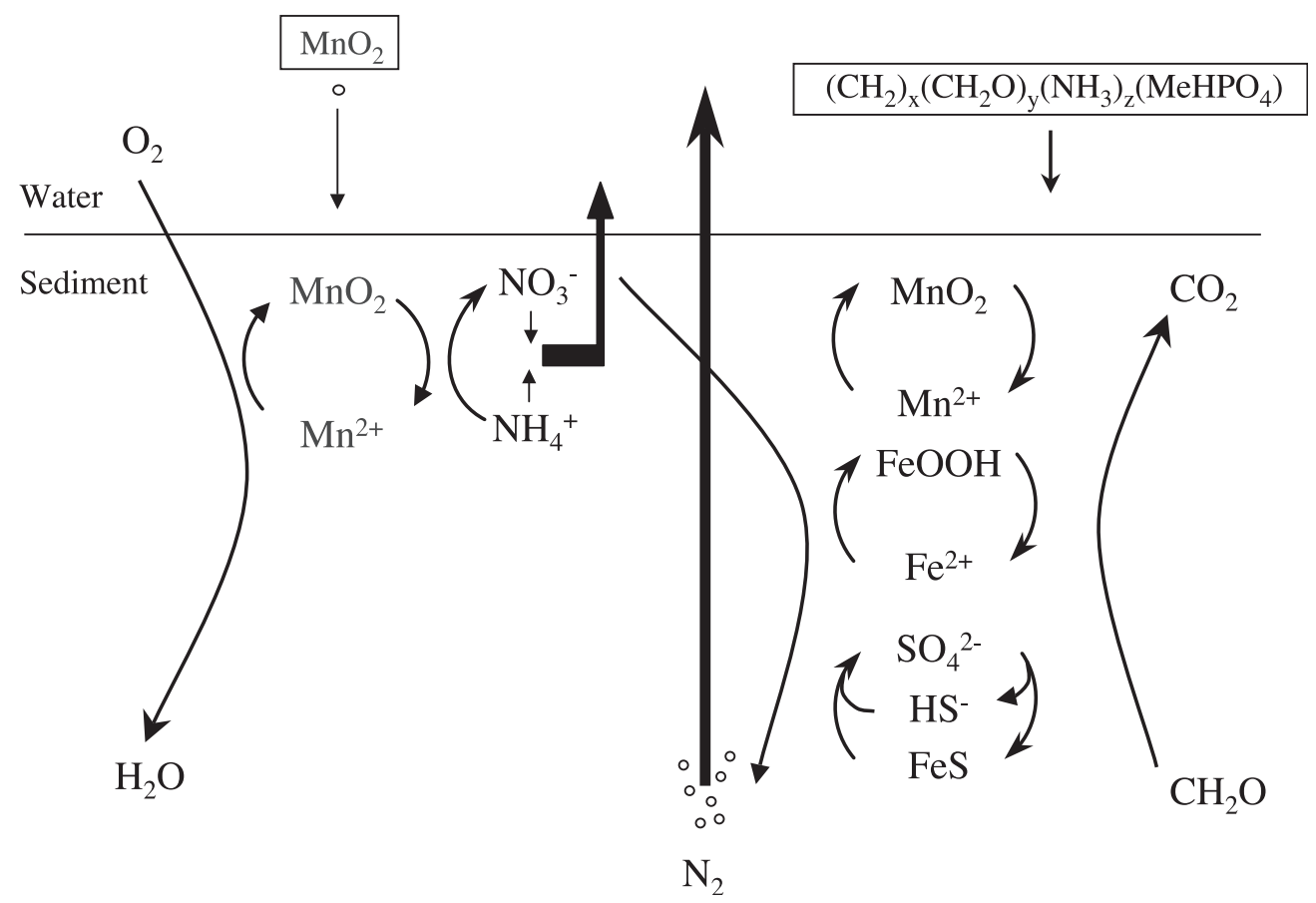

Fig. 3. In addition to the traditionally accepted nitrification/denitrification cycle, alternative pathways of $\mathrm{N}$ transformations can be achieved, e.g., through anaerobic ammonium oxidation during manganese or nitrate/nitrite reduction. Reduction of nitrate mobilized anaerobically may occur in a complex reaction web including several possible reductants in anaerobic sediments (e.g., $\mathrm{Mn}^{2+}, \mathrm{Fe}^{2+}$, $\mathrm{HS}^{-}$and labile Fe-sulfides). One example of a favourable reductant of nitrite in anaerobic environments is ammonium during the anammox reaction. 
Pore water distributions of oxygen and nitrogen species and the solid phase distribution of manganese in shelf and hemipelagic sediments sometimes indicate a coupling between the manganese-oxide reduction and ammonium (or nitrite; Luther and Popp, 2002) oxidation to either $\mathrm{NO}_{3}^{-}$(Anschutz et al., 2000; Bender, 1982; Bender et al., 1989; Dhakar and Burdige, 1996; Goloway and Bender, 1982; Hulth et al., 1999) or directly to $\mathrm{N}_{2}$ (Luther et al., 1997). Thermodynamic calculations and experimental manipulations indicate that anaerobic ammonium oxidation coupled to manganese reduction is energetically favourable (Hulth et al., 1999; Luther et al., 1997). For example, experimental observations demonstrated anaerobic mobilization of $\mathrm{NO}_{2}^{-}$and $\mathrm{NO}_{3}^{-}$ at rates similar to, or even higher than, rates reported for coastal marine sediments open for $\mathrm{O}_{2}$ diffusion (Hulth et al., 1999). Patterns of nitrite/nitrate production and subsequent consumption were directly related to the content of Mn-oxides in the solid phase of the sediment, and consistent with coupled nitrification/denitrification in the completely anoxic sediment. Suggested reactions of anaerobic ammonium oxidation imply solid phase Mn-oxides, but do not exclude soluble and often more reactive colloidal $\mathrm{Mn}$ (III, IV)-species as important reactants (Kostka et al., 1995). Ammonium oxidation coupled to Mn-oxide reduction is apparently not an obligately aerobic process as often postulated, although microorganisms capable of this anoxic metabolism have yet to be discovered.

The process of anaerobic ammonium oxidation to $\mathrm{N}_{2}$ or $\mathrm{NO}_{2}^{-} / \mathrm{NO}_{3}^{-}$by Mn-oxides has not been directly demonstrated in natural marine sediments, but rather indirectly inferred from solute distributions in the water column or sediment pore waters with/without manipulations of the sediment (Anschutz et al., 2000; Hulth et al., 1999). Investigations using ${ }^{15} \mathrm{~N}$ tracers in the anoxic, Mn-rich sediment of the deep Skagerrak could not verify the reaction (Thamdrup and Dalsgaard, 2000, 2002), possibly related to $\mathrm{N}$ limitation at the investigated site. However, there was also no detectable production of ${ }^{15} \mathrm{NO}_{3}^{-}$or ${ }^{29 / 30} \mathrm{~N}_{2}$ during later experiments including amendments of ${ }^{15} \mathrm{~N}$-labelled algal material (Dunaliella spp.) in the deep Skagerrak (Hulth et al., unpublished). An additional explanation for observations of nitrate mobilization in anoxic sediments could be the release of nitrate from bacteria or phytoplankton during experimental manipulations. For example, the sulfide-oxidizing giant bacterium Thioploca couples sulfide oxidation with nitrate reduction to ammonium (Jørgensen and Gallardo, 1999). Nitrate is contained in a central vacuole at concentrations up to $0.5 \mathrm{M}$ (Fossing et al., 1995). Thus, during processing to separate pore water from sediment, cell lysis and disruption of cell walls may release significant quantities of nitrate to the pore water. Giant bacteria such as Thioploca and Thiomargarita with a pronounced capacity to internally store substantial amounts of nitrate are relatively widespread in coastal marine sediments (Jørgensen and Gallardo, 1999). Their eventual quantitative role during $\mathrm{N}$ mineralization and the overall $\mathrm{N}$ cycle is, however, poorly investigated (Jørgensen, 1977). Similarly, Lomstein et al. (1990) observed erroneously high pore water nitrate concentrations due to the disruption of fresh phytoplankton cells during processing of sediment. Contamination from intracellular nitrate was estimated $>100 \mu \mathrm{M}$. However, it is less likely that the time-dependent, down-core mobilization/removal patterns of nitrite and nitrate observed, e.g., by Gilbert et al. (2003) and Hulth et al. (1999), were caused by artefacts such as those described above, but rather due to the alternative route of anaerobic ammonium oxidation coupled to manganese (III/IV) reduction.

Further observations of additional links between the $\mathrm{N}$ and $\mathrm{Mn}$ redox cycles have been reported during studies at the oxic-anoxic interface of the Black Sea, and sediments of the equatorial Atlantic, Cabot Strait, Scotia slope, and the Panama Basin. For example, in addition to anaerobic ammonium oxidation by $\mathrm{Mn}$ oxides, solute distribution patterns suggested anaerobic $\mathrm{Mn}$ (II) oxidation coupled to nitrate reduction (Aller, 1990; Aller et al., 1998; Luther et al., 1997; Murray et al., 1995; Schultz et al., 1994; Shaw et al., 1990; Tebo, 1991). Indications of microbial Mn(II) oxidation are frequently reported in the literature, but depending on the assumed form of $\mathrm{MnO}_{2}$, this reaction is not thermodynamically favourable except at conditions of elevated $\mathrm{NO}_{3}^{-}$concentrations and high $\mathrm{pH}$ (Hulth et al., 1999). A chemolithotrophic bacterium that generates energy for autotrophic growth by coupling $\mathrm{Mn}$ (II) oxidation to aerobic or anaerobic respiration has not been described (Tebo et al., 1997). Direct measurements of anaerobic Mn- 
oxidation coupled to $\mathrm{NO}_{3}^{-} / \mathrm{NO}_{2}^{-}$reduction in marine waters have, to our knowledge, not been reported.

Observations of an anaerobic pathway for nitrate formation and the pronounced availability of reductants in anoxic sediments suggest that additional coupled reactions of $\mathrm{N}_{2}$ production occur in parallel or in series (Fig. 3). These oxidation/reduction pathways could generally be described as a complex network of overlapping biotic and abiotic reactions (Emerson et al., 1982; Hulth et al., 1999; Lovley, 1991; Nealson and Stahl, 1997; Sørensen et al., 1987). As there are numerous possible reductants for $\mathrm{NO}_{3}^{-}$ mobilized under anaerobic conditions (e.g., POC, DOC, $\mathrm{NH}_{4}^{+}, \mathrm{Fe}_{2}^{+}, \mathrm{HS}^{-}, \mathrm{S}^{0}, \mathrm{FeS}$, and $\mathrm{FeS}_{2}$ ), anaerobic ammonium oxidation to nitrate may not always be evident as a net reaction when examining solute distributions in the water column or sediment pore water where denitrification is active. Little information is available on the likely importance of bacteria for these reactions, and the relative contribution of each pathway to element cycling in aquatic ecosystems (Burdige, 1993; Canfield et al., 1993a; Luther et al., 1997; Tebo, 1991; Thamdrup et al., 1994). For example, sulfate-reducing bacteria (e.g., Desulfovibrio desulfuricans) are in generally quite versatile to electron acceptors and some of these may switch from sulfate to nitrate or oxygen reduction in response to changing environmental conditions (Cypionka, 1994). If nitrate is present, the bacterium may oxidize reduced sulfur compounds to sulfate during concurrent formation of $\mathrm{NH}_{4}^{+}$(Jørgensen, 1977). Nitrogen is thus retained in the system.

The microbiology and biogeochemistry of $\mathrm{Fe}$ redox cycling have been comprehensively reviewed in progressive response to discoveries in the laboratory and observations made in the field (e.g., Burdige, 1993; Thamdrup, 2000). Nitrate reduction coupled to $\mathrm{Fe}^{2+}$ oxidation has been reported for a variety of denitrifying bacteria (Benz et al., 1998; Hafenbradl et al., 1996; Straub et al., 1996; Straub and Buchholz-Cleven, 1998), and for Geobacter metallireducens which reduces nitrate to ammonium (Finneran et al., 2002). Many of the known ironreducing bacteria can also respire through dissimilatory nitrate/nitrite reduction to ammonium (Lovley, 2000). The oxidation of $\mathrm{NH}_{4}^{+}$by $\mathrm{FeOOH}$ is, however, not thermodynamically favourable at the normal $\mathrm{pH}$ of seawater and concentrations of $\mathrm{Fe}^{2+}$ measured in non-sulfidic pore waters (Anschutz et al., 2000; Hulth et al., 1999). Although a direct link between $\mathrm{Fe}$ and $\mathrm{N}$ in the anaerobic ammonium oxidation by Fe-oxides is less likely, there seem to exist several possible additional pathways to link the iron and the nitrogen cycles and thereby further contribute to the complexity of anaerobic $\mathrm{N}$-transformations in marine environments.

\section{2. $N$ removal by concomitant ammonium oxidation and nitrite reduction}

As described above, several experimental and model observations have demonstrated ammonium oxidation under anaerobic conditions in marine environments (Fig. 1). In addition, nitrate reduction may well proceed through other pathways than the oxidation of organic carbon (Fig. 3). A thermodynamically favourable reductant of nitrite and nitrate under anaerobic conditions is ammonium. Based on the relative distributions of ammonium, nitrate, and oxygen in water columns and thermodynamic considerations, the occurrence and biological feasibility of such process was predicted already some decades ago (Broda, 1977; Richards, 1965). However, it was not until 1995 that Mulder et al. directly demonstrated the reaction in a denitrifying pilot plant reactor of a wastewater treatment system. Although not yet isolated in pure cultures, the microbes involved (Strous et al., 1999a) and the catalytic pathway (Jetten et al., 1999; Jetten et al., 2001; Strous et al., 1999b; Van de Graaf et al., 1995) of the so-called anammox (ANaerobic AMMonium OXidation) process have been described. Strous et al. (1999a) identified a lithotrophic bacterium capable of anaerobic ammonium oxidation to $\mathrm{N}_{2}$ during $\mathrm{CO}_{2}$ fixation. On the basis of $16 \mathrm{~S}$ rDNA phylogeny, microbial consortia dominated by deep-branching members of the Planctomycetales (Candidatus "Brocadia anammoxidans" and its relative Candidatus "Kuenenia stuttgartiensis") were suggested to catalyze the process (e.g., Strous et al., 1999a; Jetten et al., 2001). Amendments using ${ }^{15} \mathrm{~N}$ and subsequent patterns of ${ }^{28 / 29 / 30} \mathrm{~N}_{2}$ mobilization have confirmed that energy is derived via a novel metabolic pathway involving $\mathrm{NH}_{4}^{+}$as electron donor, $\mathrm{NO}_{2}^{-}$as the preferred electron acceptor with hydroxylamine and hydrazine as intermediates (Van de Graaf et al., 1995, 1996). Concomitant organotrophic nitrate 
reduction was suggested as the source of nitrite (Van de Graaf et al., 1995). In contrast to more traditional denitrification, ammonium may, through this route of nitrite reduction, be directly oxidized and converted to $\mathrm{N}_{2}$ seemingly without the simultaneous production of the intermediate $\mathrm{N}_{2} \mathrm{O}$ and the end product $\mathrm{CO}_{2}$ (e.g., Van de Graaf et al., 1995). In addition to that $\mathrm{CO}_{2}$ and $\mathrm{N}_{2} \mathrm{O}$ are important greenhouse gases, a net $\mathrm{N}_{2} \mathrm{O}$ production to the atmosphere is undesirable due to the ozone depletion in the stratosphere (Crutzen, 1970). Investigations in wastewater systems have confirmed anammox as an autotrophic process, even more energetically favourable than traditional nitrification in oxic environments (Jetten et al., 2001; Strous, 2001). Nitrite, one of the intermediate products formed during nitrification and denitrification (Fig. 1 ), is rarely accumulated at elevated concentrations in aquatic systems. Concentrations are often close to or below detection. The reduction of nitrate to nitrite appears to be a prerequisite for ammonium oxidation by nitrite to gain access to the pool of nitrate, which is generally significantly larger than the pool of nitrite. However, when the first steps in the denitrification pathway $\left(\mathrm{NO}_{3}^{-}\right.$to $\mathrm{NO}_{2}^{-}$and $\mathrm{NO}_{2}^{-}$to $\left.\mathrm{N}_{2} \mathrm{O}\right)$ are uncoupled, there is a potential for $\mathrm{NO}_{2}^{-}$accumulation. Accumulation of $\mathrm{NO}_{2}^{-}$is also possible during nitrification, when ammonium oxidation to nitrite is decoupled from further oxidation to nitrate. Anaerobic ammonium oxidizers and aerobic nitrifying bacteria coexist under oxygen limiting conditions where nitrifiers oxidize ammonium to nitrite and deplete oxygen, while the anammox bacteria convert toxic nitrite and the remaining ammonium to $\mathrm{N}_{2}$ (Sliekers et al., 2002).

Overall characteristics of the anammox process are quite remarkable, especially considering the high toxicity of the intermediates hydroxylamine and hydrazine. Hydrazine, for example, is used as rocket fuel and constitutes an intermediate in the production of explosives and pesticides (Molinder and Street, 1989). Interestingly, Damsté et al. (2002) discovered four-membered aliphatic cyclobutane rings in the membrane lipids ("ladderanes") of cell compartments within the Planctomycetales where anammox catabolism takes place. Such unique signature of confined lipid structures gives rise to an exceptionally dense membrane and a tight barrier against diffusion. Furthermore, a compact membrane structure would most likely stabilize concentration gradients during the anammox metabolism and contain the toxic intermediates, thereby protecting the remainder of the cell from damage (DeLong, 2002). Advantages compared to the traditional coupled nitrification/ denitrification in wastewater treatment include lower oxygen demand (nitrifying bacteria require oxygen for partial oxidation of ammonium to nitrite) and no requirement for external $\mathrm{C}$ sources because the process is autotrophic. However, net efficiency of the process is likely reduced by the slow growth rate observed for the anammox bacteria, dividing only once every 2-3 weeks (Jetten et al., 1999, 2001). Although the bacteria grow extremely slowly, net ammonium removal may be significant (Van Loosdrecht and Jetten, 1998; Zehr and Ward, 2002). The reaction of anaerobic ammonium oxidation is obviously of great practical interest given the need to remove $\mathrm{N}$ from, e.g., wastewater. However, arguments of removing $\mathrm{N}$ also hold for coastal marine environments.

\subsection{Anaerobic ammonium oxidation by nitrite in marine environments}

The potential ecological impact of anaerobic ammonium oxidation to either nitrate or $\mathrm{N}_{2}$ is not well understood. One prerequisite for anammox would be the simultaneous presence of both ammonium and nitrite in the absence of oxygen. The reaction is strongly, but reversibly, inhibited by molecular oxygen (Jetten et al., 1999). Nitrite could be accumulated in ecosystems where oxygen limits nitrification, or in systems with a limited supply of reductants for denitrification of nitrate. The oxic/ anoxic interface of sediments or stratified waters with a well-developed suboxic layer would be almost ideal. Also, overlapping distributions of nitrite and ammonium have been reported in oxygen-limited biofilms (Schramm et al., 1996).

Ammonium often accumulates in anoxic environments due to the lack of aerobic nitrification. On the basis of inorganic $\mathrm{N}$ distributions, anaerobic ammonium oxidation in marine environments has been implied in the past, but $\mathrm{N}$ mass balances from ammonium and nitrate distributions were not precise enough to confirm any missing nitrogen. For example, a reaction stoichiometry similar to that described for 
anammox was suggested in the mid 1960s in anoxic basins of the Framvaren Fjord and the Black Sea (Richards, 1965). Although indications of this novel route of nitrate/nitrite reduction by ammonium were proposed by Bender et al. (1989), Dhakar and Burdige (1996), Goloway and Bender (1982), Murray et al. (1995), and Schultz et al. (1994), recent studies in Skagerrak and Kattegatt sediments for the first time provided direct experimental evidence of ammonium oxidation by nitrite (Dalsgaard and Thamdrup, 2002; Engström et al., 2004; Thamdrup and Dalsgaard, 2002). Single and coupled amendments of ${ }^{15} \mathrm{~N}$ labelled ammonium and nitrate demonstrated that the reaction contributed $<5 \%$ to $\sim 70 \%$ to total $\mathrm{N}_{2}$ production in anoxic marine sediments at several sites in the Baltic-North Sea transition. That is, in some sedimentary environments the anammox process was even more important than traditional denitrification for $\mathrm{N}_{2}$ formation and $\mathrm{N}$ removal (Fig. 4). Furthermore, nutrient profiles, fluorescently labelled RNA probes, ${ }^{15} \mathrm{~N}$ tracer experiments, and distributions of the specific "ladderane" lipids (Damsté et al., 2002) clearly demonstrated that a significant fraction of ammonium diffusing upwards from the anoxic deep- water of the Black Sea was consumed by anammox bacteria below the oxic zone (Kuypers et al., 2003). Additionally, anammox was found to account for 19$35 \%$ of total $\mathrm{N}_{2}$ formation in the water column of Golfo Dulce, a coastal bay in Costa Rica (Dalsgaard et al., 2003). In both cases of anammox activity reported in the water column, the depth interval of the process was narrowly constrained to anoxic waters where nitrate and nitrite were present. Notably, the water column chemistry of the Golfo Dulce is very similar to that in oxygen depleted zones of the oceans, sites in which $30-50 \%$ of global $\mathrm{N}$ removal is believed to occur (Gruber and Sarmiento, 1997). Taken together, these studies present compelling evidence from both sediment and water column environments that the anammox reaction may be a globally important, but so far mostly overlooked, sink for oceanic nitrogen. Anammox is probably carried out by a type of bacteria similar to those previously isolated from bioreactors.

One might expect that the activity levels of microbial populations are highly coupled to the amount and composition of organic matter. Indeed, the variability in the relative contribution of anammox

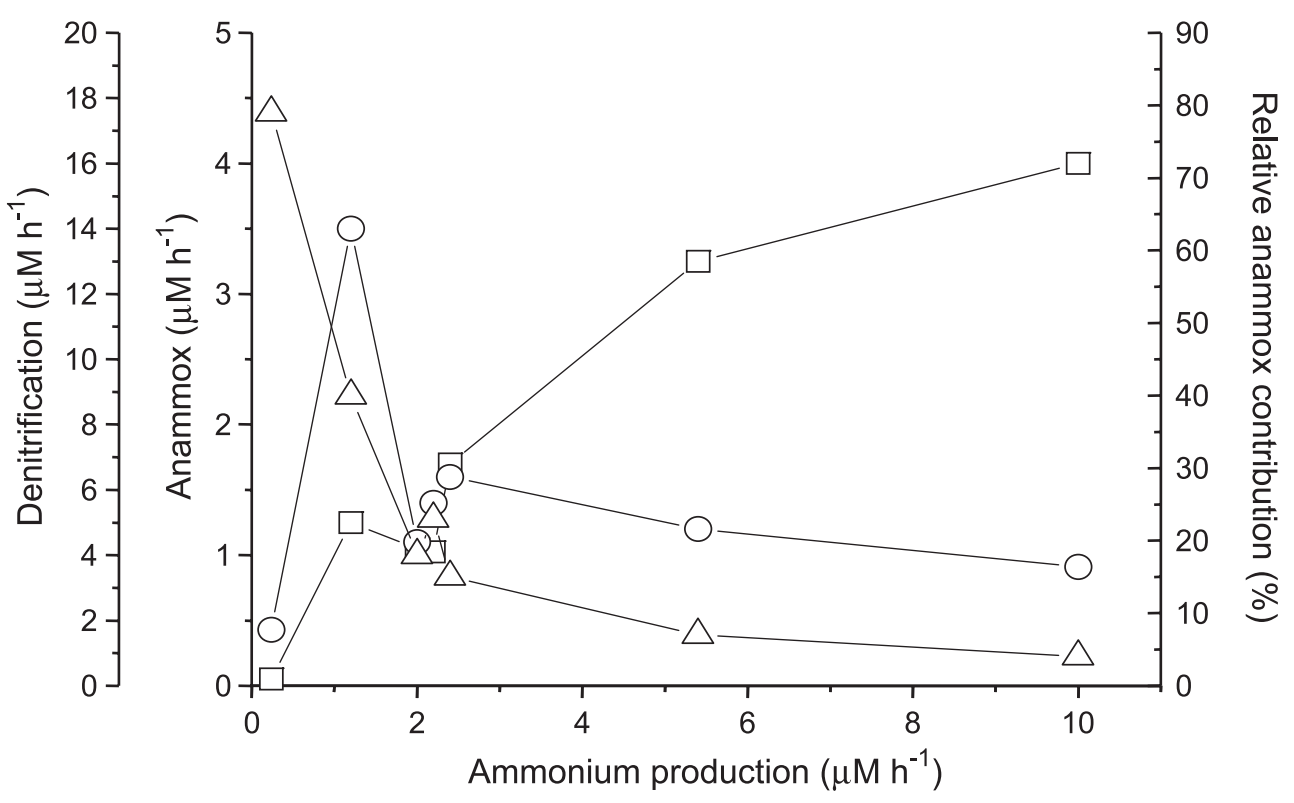

Fig. 4. General illustration of the importance of anaerobic ammonium oxidation by nitrite (anammox) for total $\mathrm{N}_{2}$ production observed at several sites in the Baltic-North Sea transition (Engström et al., 2004; Thamdrup and Dalsgaard, 2002). With increasing sediment reactivity, as evidenced by ammonium mobilization during closed sediment incubations, there was a decreasing importance of anammox for total sediment $\mathrm{N}_{2}$ production (i.e., denitrification becomes progressively more important; open triangles). Concurrently, absolute rates of denitrification (open squares) increased in a relatively linear fashion over the reactivity interval investigated. Rates of anammox, however, reached a maximum value at intermediate reactivities (open circles). 
and denitrification to total $\mathrm{N}_{2}$ production was found related to organic carbon reactivity and the availability of reductants in sediments (Engström et al., 2004; Thamdrup and Dalsgaard, 2002). Elevated access to reduced compounds seemed to favour denitrification compared to anammox, and there was a negative exponential correlation between the importance of anammox for total $\mathrm{N}_{2}$ production and rates of ammonium mobilization to the pore water (Fig. 4). While absolute rates of denitrification increased with sediment reactivity, rates of ammonium oxidation coupled to nitrite reduction seemed to reach a maximum at intermittent reactivity, possibly related to the availability of nitrite. Uncoupling between $\mathrm{NO}_{3}^{-}$ and $\mathrm{NO}_{2}^{-}$reduction was directly observed in the study by Dalsgaard and Thamdrup (2002) as transient accumulation of high levels of $\mathrm{NO}_{2}^{-}$in sediment incubations following additions of $\mathrm{NO}_{3}^{-}$. Measured $\mathrm{NO}_{2}^{-}$production rates were approximately four times faster than its consumption in the Skagerrak sediment where the alternative pathway was found most significant for $\mathrm{N}_{2}$ production $(\sim 70 \%)$.

\section{Implications of alternative pathways for $\mathbf{N}$ removal in marine environments}

Bioavailable nitrogen is removed from the sea mainly by denitrification (including the novel routes of $\mathrm{N}$ removal, e.g., anammox), burial of organic and inorganic $\mathrm{N}$ in the sedimentary record, and removal following biomass incorporation (Devol, 1991; Middelburg et al., 1996; Seitzinger, 1988; Wollast, 1991). Although the respiratory reduction of nitrate through denitrification (preferably in continental margin sediments) is presently considered the most important process for oceanic $\mathrm{N}$ removal (Christensen et al., 1987; Christensen, 1994), the magnitude and relative importance of nitrogen-removing pathways vary significantly with season and geographical location (Christensen et al., 1987; Hedges and Keil, 1995; Middelburg et al., 1996; Wollast, 1991). Over the last few decades, denitrification has been investigated not only on the continental shelves (Christensen et al., 1987; Devol, 1991), but also in the oxygen minimum zones of the water column, particularly in the Indian (Naqvi et al., 1982) and tropical Pacific Oceans (Codispoti and Christensen, 1985; Hattori, 1983).
Water column denitrification is currently thought to account for 60 to $290 \mathrm{Tg} \mathrm{N}$ year $^{-1}$, while benthic environments remove a similar amount $(60-285 \mathrm{Tg} \mathrm{N}$ year $\left.^{-1}\right)$, of which about $50 \%\left(\sim 100 \mathrm{Tg} \mathrm{N}\right.$ year $\left.^{-1}\right)$ is assumed to be removed in coastal and shelf sediments (Brandes and Devol, 2002; Capone, 2000; Codispoti et al., 2001; Middelburg et al., 1996; Seitzinger, $1988)$. The difference between total denitrification $\left(\approx 120-575 \mathrm{Tg} \mathrm{N}\right.$ year $\left.^{-1}\right)$ and total $\mathrm{N}$ fixation $(\approx 25-$ $200 \mathrm{Tg} \mathrm{N}$ year $^{-1}$ ) is on the order of $100-200 \mathrm{Tg} \mathrm{N}$ year $^{-1}$, i.e., roughly similar to what can be estimated for the difference between sources and sinks of $\mathrm{N}$ in the ocean (e.g., Capone, 2000; Codispoti et al., 2001; Middelburg et al., 1996). There is no doubt that significant advancements on nitrogen biogeochemistry have been made during the last few decades. However, the apparent imbalance between sources and sinks of nitrogen and the large range of rate estimates is intriguing and indicates that overall knowledge on the marine $\mathrm{N}$ cycle is still insufficient and perhaps not reflective of the highly dynamic oceanic environment. There is, however, not a reason to assume a completely balanced oceanic nitrogen budget as a steady state situation is eventually reached only over time scales similar to those of ocean mixing (Codispoti, 1989).

The qualitative and quantitative importance of alternative reactions for global nitrogen removal and their controlling mechanisms are not well known. Overall, contributions to the marine $\mathrm{N}$ budget are based on a relatively limited number of measurements, obtained on small temporal and spatial scales. As several $\mathrm{N}$ compounds have short turnover rates in the various reservoirs, large local and regional deviations from the global mean values of fluxes and concentrations are likely. Extrapolating to a global scale is therefore difficult. To date, the very few investigations on alternative $\mathrm{N}$ cycle pathways have been performed using manipulated sediment or water samples, with limited frequency of sampling throughout the year. Possible seasonal cycles in rates and mechanisms, and eventual links coupled to the quantity and quality of the organic material, are poorly known. These alternative reactions are in fact examples of pathways that should be included in the regulatory characteristics of the $\mathrm{N}$ cycle and systematically considered when constructing conceptual models for nitrogen dynamics in marine environments. 
Where are these alternative processes during $\mathrm{N}$ mineralization likely to occur? Using the availability of reductants and metal oxides, and the simultaneous requirements of $\mathrm{NH}_{4}^{+}$and $\mathrm{NO}_{2}^{-}$(anammox), as a key to estimate the relative importance of alternative routes during $\mathrm{N}$ removal in marine environments, we expect the new processes to be significant for $\mathrm{N}$ cycling above all in close proximity to oxic/anoxic interfaces. They are possibly also important for $\mathrm{N}$ removal in the oxygen minimum zones, not directly associated with redox interfaces. Availability of Mnand Fe-oxides seems to occasionally accelerate total rates of $\mathrm{N}_{2}$ formation and to promote the relative importance of anammox compared to traditional denitrification during $\mathrm{N}$ mineralization in surface sediments (Hulth et al., 1999; Engström et al., 2004). An oxic/anoxic interface is readily established close to the sediment-water interface in benthic environments, especially in coastal regions with a high supply of organic matter (Revsbech et al., 1980). In addition, large suboxic systems, such as sediments of the Panama Basin and massive deltaic deposits typified by the Amazon shelf, may be regions of extensive denitrification and concomitant metal-nitrogen coupling (Aller et al., 1998). Although pronounced oxic/anoxic boundaries may also be observed in the water column (Murray et al., 1995), most sites have a very small or no suboxic transition zone. However, in certain areas of the oceans there are extensive vertical zonations of suboxic mineralization. The well-stratified Black Sea, for example, has a particularly well-developed suboxic zone, and the complete progression of reactants seems well resolved in a predictable and reproducible way on characteristic density surfaces (e.g., Murray et al., 1989, 1995). As discussed above, simultaneously using an array of microbiological and biogeochemical techniques, Kuypers et al. (2003) provided direct evidence of anammox activity in the Black Sea water column. Comparative calculations suggested that anammox consumed more than $40 \%$ of the fixed nitrogen that enters the anoxic Black Sea bottom water. Also, anammox was found to account for about one-third of total $\mathrm{N}_{2}$ formation in the Golfo Dulce (Dalsgaard et al., 2003).

All in all, the high rates of anammox activity detected in waters similar to those in the oxygen minimum zones, combined with the lower-level but most likely more widespread anammox activity in benthic environments, indicate that alternative pathways may account for between $25 \%$ and $50 \%$ of the marine $\mathrm{N}_{2}$ production (Dalsgaard et al., 2003; Devol, 2003). Locally, however, the relative importance may be significantly higher (Dalsgaard and Thamdrup, 2002; Thamdrup and Dalsgaard, 2002; Engström et al., 2004), possibly due to the decomposition of $\mathrm{N}$-rich organic material or the supply of ammonium from outside the anammox zone (Ward, 2003). To validate recently reported observations, quantitative and qualitative information is needed from above all the oxygen minimum zones of the Indian and tropical Pacific Oceans, benthic deep-sea and suboxic environments, and sulfide-bearing basins and fjords like the Carriaco Trench and the Orca Basin in the Gulf of Mexico (Van Cappellen et al., 1998). Furthermore, eventual diurnal variability of alternative pathways for $\mathrm{N}$ removal is unknown. For example, there is no information available from shallow-water $(<2 \mathrm{~m})$ sediment systems. In these illuminated sediments, the autochthonous production of organic material can be high throughout the year due to the presence of benthic primary producers, such as microphytobenthos (e.g., Sundbäck et al., 2000), which also directly and indirectly influence benthic $\mathrm{N}$ cycling (e.g., Sundbäck and Miles, 2000; Risgaard-Petersen, 2003). Due to organic material supplied from land and microphytobenthic activity in surface sediments, shallow-water environments are often highly reactive. According to the direct coupling between the availability of reductants in the pore water $(\approx$ reactivity) and the importance of anammox for total N removal (Engström et al., 2004; Thamdrup and Dalsgaard, 2002; Fig. 4), model predictions suggest that anammox is a very minor process in these types of sediments. On the other hand, by activities of microbenthic algae there is a diurnal supply of oxygen to the surface layer of the sediment. Availability of oxidants like oxygen (and Fe- and Mn-oxides) induces lower concentrations of reduced metabolites in the pore water. Such conditions seem to favour anammox compared to more traditional denitrification. Thus, there are conflicting model predictions for anammox in illuminated shallow-water sediments with microphytobenthic activities. 


\section{Outlook for future research}

The application of $\mathrm{N}$ isotopes and the specific relation between ${ }^{14} \mathrm{~N}$ and ${ }^{15} \mathrm{~N}$ in PON, DON, $\mathrm{NH}_{4}^{+}$, $\mathrm{NO}_{2}^{-}, \mathrm{NO}_{3}^{-}$of natural and manipulated systems have significantly enhanced overall knowledge on rates and pathways in the N cycle (Nielsen, 1992; Peterson and Howarth, 1987). Studies often utilize the isotopic fractionation by biological and chemical transformations that affect the relative abundance of natural ${ }^{14} \mathrm{~N}$ and ${ }^{15} \mathrm{~N}$, and the discrete pairing of artificially added ${ }^{14} \mathrm{~N}$ and ${ }^{15} \mathrm{~N}$ ions that gives rise to different formation patterns of ${ }^{28 / 29 / 30} \mathrm{~N}_{2}$. Absolute and relative rates of mobilization depend on the relative abundance of the respective ion, and if nitrate for nitrate reduction is obtained from the overlying water or from coupled nitrification/denitrification in the surface sediment (Nielsen, 1992). Eventual presence of anammox, however, violates central assumptions of the isotope pairing technique. In sediments where denitrification and anammox coexisted, the error in total $\mathrm{N}_{2}$ production estimates imposed by anammox was up to $80 \%$ relative to estimates using a revised stoichiometry of $\mathrm{N}$ mineralization (Risgaard-Petersen et al., 2003). The difference was most pronounced at the site where anammox dominated $(\approx 70 \%)$ total $\mathrm{N}_{2}$ production. There is thus a need to further confirm and validate the limited data set available comprising simultaneous information on both anammox and denitrification measured by the isotope pairing technique. Also, sediment anammox rates have so far exclusively been quantified in sediment-water slurries or closed jar incubations of surface sediments. The agreement between manipulated sediment incubations and intact sediment communities has to be further investigated.

In addition to a suitable experimental design including, e.g., intact surface sediment and ambient bottom water, technical developments in resolving pore water distributions at submillimeter resolution by microscale optical, biological and electrochemical sensors (Gundersen and Jørgensen, 1990; Kühl and Revsbech, 2001; Luther et al., 1994, 1998; Revsbech et al., 1980; Wolfbeis, 1991), and water/gel-filled equilibration probes (Davison et al., 1991, 1994; Hesslein, 1976), would most likely improve the overall understanding of alternative routes during $\mathrm{N}$ removal in marine sediments. By the assumption that vertical gradients represent a steady-state situation, high-resolution (temporal and spatial) reaction-diffusion models can be applied to estimate rates of aerobic respiration, nitrification and denitrification, and to calculate the importance of these processes in relation to the observed solute distribution patterns (e.g., Berg et al., 2003; Christensen and Rowe, 1984; Gilbert et al., 2003; Jahnke et al., 1982; Vanderborght and Billen, 1975). There is, however, a need to improve the performance and characteristics of microsensors for ammonium and nitrate in seawater (Meyer et al., 2001; Revsbech, 1990). A promising principle for optical detection of ammonium in aquatic systems was recently presented (Strömberg and Hulth, 2001, 2003). Efforts are now being made to adapt the technique to fibre-optic microsensors for ammonium (Hulth et al., unpublished). Two-dimensional plate sensors, so far developed for $\mathrm{O}_{2}$, (Glud et al., 1996) and $\mathrm{pH}$ (Hulth et al., 2002), provide important complementary microscale level information on the temporal and spatial variability of alternative reactions during benthic $\mathrm{N}$ mineralization, particularly close to the oxic/anoxic transition and in the suboxic layer of the sediment. A future ability to simultaneously and non-destructively scan 2-D distributions of biogeochemically important solutes like $\mathrm{O}_{2}, \Sigma \mathrm{CO}_{2}$, nutrients, $\mathrm{Mn}, \mathrm{Fe}$, and $\mathrm{pH}$ would significantly improve the understanding of complex reaction cycles during organic matter degradation.

Nitrogen cycling is subject to a complex array of regulatory mechanisms, some of which are mediated by a metabolically diverse range of microorganisms. There is an obvious lack of knowledge on links and feedback mechanisms between ecosystem functionality and bacterial community structure of natural marine ecosystems. For example, the diversity of bacteria in benthic environments is far from being fully explored, and may yet hold many surprises. Recently introduced immunological and molecular methods provide sensitive means of detecting important enzymes and genes of bacterial populations directly involved in $\mathrm{N}$ cycle transformations in their natural environments. Such methodologies may thus provide important information on actual control mechanisms of alternative, not well-known routes during $\mathrm{N}$ mineralization (e.g., Bothe et al., 2000). Importantly, a large fraction of the bacteria extensively studied in pure cultures are not necessarily the 
major players in natural marine habitats. Central research thus remains to be performed on the molecular biology, physiology, and ecology of anammox. The highly expansive field of molecular technologies is, however, largely outside the scope of the present contribution, and for further information we refer the interested reader to current publications on the subject (e.g., Allen et al., 2001; Caffrey et al., 2003; Golet and Ward, 2001).

In addition to direct photosynthetic mobilization of oxygen in the surface layer of shallow-water sediments, oxygen may be supplied to anoxic regions of the sediment by macrofaunal reworking activities (e.g., Aller, 2001). Sediment-inhabiting animals have frequently far-reaching effects on the oxic/anoxic interface and the multi-dimensional distribution of solutes (Aller, 1982; Brune et al., 2000). Highresolution 1- and 2-D profiles of important redox dependent species often support the conceptualization of bioturbated sediments as a spatially and temporally changing mosaic of reactions, complementing those normally considered during organic matter diagenesis. Sediment reworking and bioirrigation play a major role for the sedimentary N-cycle, e.g., by stimulating coupled nitrification-denitrification and/or direct denitrification from overlying water nitrate (Aller et al., 1983; Gilbert et al., 2003; Kristensen and Blackburn, 1987; Pelegri et al., 1994; Rysgaard et al., 1995). Due to the continuous resuspension and mixing downward of metal-oxide enriched sediments, bioturbation may in fact also constitute one of the major factors in establishing conditions favourable for alternative pathways involving nitrogen- and metalredox coupling (Hulth et al., 1999; Luther et al., 1997). However, the importance of various types of macrofauna (including interactions between species) and the quantitative importance of alternative routes induced by macrofaunal reworking and irrigation are virtually unknown. Laboratory and in situ studies involving different functional groups (monospecific to whole community) and densities of macrofauna are needed as they would provide important information on how sediments devoid of larger fauna respond in comparison to a well-developed sediment community.

To conclude, alternative $\mathrm{N}$ cycle routes such as anaerobic ammonium oxidation by nitrite and coupled nitrification/denitrification of nitrate produced in anaerobic environments (e.g., by Mn-oxides) may explain ammonium deficiencies observed in the anoxic but nitrate containing zone of hemipelagic and pelagic sediments, and similar deficiencies observed in the suboxic zone of stratified waters such as the Black Sea. The anammox reaction constitutes an overlooked route to remove fixed $\mathrm{N}$ from the marine ecosystem, seemingly without the simultaneous emission of the green-house gases $\mathrm{CO}_{2}$ and $\mathrm{N}_{2} \mathrm{O}$ (Van de Graaf et al., 1995). Although originally discovered in a pilot wastewater treatment system, it seems that bacteria capable of this reaction are present also in aquatic ecosystems where they at least locally may account for more than $75 \%$ of total $\mathrm{N}_{2}$ production.

\section{Acknowledgements}

We would like to thank Prof. Em. David Dyrssen for his encouraging support and mentorship over the years. Financial support to perform several of the studies described was obtained from the Swedish Research Council (VR), the Foundation for Strategic Environmental Research (MISTRA), the Centre National de la Recherche Scientifique (CNRS), the Swedish Research Council for Environment, Agricultural Sciences and Spatial Planning (FORMAS), the Royal Society of Arts and Sciences, the PREEM Environment Foundation, the Technology Link Foundation in Göteborg (TBSG), the Adlerbert Science Foundation, and the Crafoord Foundation. We thank the Associate Editor William M. Landing and the two reviewers for constructive comments on the manuscript.

\section{References}

Allen, A.E., Booth, M.G., Frischer, M.E., Verity, P.G., Zehr, J.P, Zani, S., 2001. Diversity and detection of nitrate assimilation genes in marine bacteria. Applied and Environmental Microbiology $67,5343-5348$.

Aller, R.C., 1982. The effects of macrobenthos on chemical properties of marine sediment and overlying water. In: McCall, P.L., Tevesz, M.J.S. (Eds.), Animal-Sediment Relations. Plenum Press, New York, pp. 53-102.

Aller, R.C., 1990. Bioturbation and manganese cycling in hemipelagic sediments. Philosophical Transactions of the Royal Society of London 331, 51-68.

Aller, R.C., 2001. Transport and reactions in the bioirrigated zone. In: Boudreau, B., Jørgensen, B.B. (Eds.), The Benthic Boundary 
Layer: Transport Processes and Biogeochemistry. Oxford Press, pp. 269-301.

Aller, R.C., Rude, P.D., 1988. Complete oxidation of solid phase sulfides by manganese and bacteria in anoxic marine sediments. Geochimica et Cosmochimica Acta 52, 751-765.

Aller, R.C., Yingst, J.Y., Ullman, W.J., 1983. Comparative biogeochemistry of water in interdidal Onuphis (Polychaeta) and Upogebia (Crustacea) burrows: temporal patterns and causes. Journal of Marine Research 41, 571-604.

Aller, R.C., Hall, P.O.J., Rude, P.D., Aller, J.Y., 1998. Biogeochemical heterogeneity and suboxic diagenesis in hemipelagic sediments of the Panama Basin. Deep-Sea Research 45, 133-165.

Anbar, A.D., Holland, H.D., 1992. The photochemistry of manganese and the origin of banded iron formations. Geochimica et Cosmochimica Acta 56, 2595-2603.

Anbar, A.D., Knoll, A.H., 2002. Proterozoic ocean chemistry and evolution: a bioinorganic bridge? Science 297, 1137-1142.

Anschutz, P., Sundby, B., Lefrançois, L., Luther III, G.W., Mucci, A., 2000. Interactions between metal oxides and species of nitrogen and iodine in bioturbated marine sediments. Geochimica et Cosmochimica Acta 64, 2751-2763.

Antia, N.J., J. Harrison, P., Oliveira, L., 1991. The role of dissolved organic nitrogen in phytoplankton nutritieon, cell biology and ecology. Phycologia 30, 1-89.

Bender, M.L., 1982. Trace elements and ocean chemistry. Nature 296, 203-204.

Bender, M.L., Jahnke, R., Weiss, R., Martin, W., Heggie, D.T., Orchardo, J., Sowers, T., 1989. Organic carbon oxidation and benthic nitrogen and silica dynamics in San Clemente Basin, a continental borderline site. Geochimica et Cosmochimica Acta $53,685-697$.

Benz, M., Brune, A., Schink, B., 1998. Anaerobic and aerobic oxidation of ferrous iron at neutral $\mathrm{pH}$ by chemoheterotrophic nitrate-reducing bacteria. Archives of Microbiology 169, $159-165$.

Berg, P., Rysgaard, S., Thamdrup, B., 2003. Dynamic modeling of early diagenesis and nutrient cycling: a case study in an Arctic marine sediment. American Journal of Science 303, 905-955.

Billen, G., 1982. An idealized model of nitrogen recycling in marine sediments. American Journal of Science 282, 512-541.

Binnerup, S.J., Jensen, K., Revsbech, N.P., Hjorth Jensen, M., Sørensen, J., 1992. Denitrification, dissimilatory reduction of nitrate to ammonium, and nitrification in a bioturbated estuarine sediment as measured with ${ }^{15} \mathrm{~N}$ and microsensor techniques. Applied and Environmental Microbiology 58, $303-313$.

Bjerrum, C.J., Canfield, D.E., 2002. Ocean productivity before about 1.9 Gyr ago limited by phosphorus adsorption onto iron oxides. Nature 417, 159-162.

Blackburn, T.H., 1983. The microbial nitrogen cycle. In: Krumbein, W.E. (Ed.), Microbial Geochemistry. Blackwell Scientific Publications, Oxford, pp. 63-89.

Bothe, H., Jost, G., Schloter, M., Ward, B.B., Witzel, K.-P., 2000. Molecular analysis of ammonia oxidation and denitrification in natural environments. FEMS Microbiology Reviews 24, 673-690.
Brandes, J.A., Devol, A.H., 2002. A global marine-fixed nitrogen isotopic budget: implications for Holocene nitrogen cycling. Global Biogeochemical Cycles 16, 1120.

Braun, S.T., Proctor, L.M., Zani, S., Mellon, M.T., Zehr, J.P., 1999 Molecular evidence for zooplankton-associated nitrogen-fixing anaerobes based on amplification of the nifH gene. FEMS Microbiology, Ecology 28, 273-279.

Broda, E., 1977. Two kinds of lithotrophs missing in nature. Zeitung für Allgemeine Microbiologie 17, 491-493.

Brune, A., Frenzel, P., Cypionka, H., 2000. Life at the oxic-anoxic interface: microbial activities and adaptations. FEMS Microbiology Reviews 24, 691-710.

Burdige, D.J., 1993. The biogeochemistry of manganese and iron reduction in marine sediments. Earth-Science Reviews $35,249-284$.

Caffrey, J.M., Harrington, N., Solem, I., Ward, B.B., 2003. Biogeochemical processes in a small California estuary. 2. Nitrification activity, community structure and role in nitrogen budgets. Marine Ecology. Progress Series 248, 27-40.

Canfield, D.E., 1998. A new model for Proterozoic ocean chemistry. Nature 396, 450-453.

Canfield, D.E., Teske, A., 1996. Late Proterozoic rise in atmospheric oxygen concentration inferred from phylogenetic and sulphur-isotope studies. Nature 382, 127-132.

Canfield, D.E., Jørgensen, B.B., Fossing, H., Glud, R., Gundersen, J.K., Ramsing, N.B., Thamdrup, B., Hansen, J.W., Nielsen, L.P., Hall, P.O.J., 1993. Pathways of organic carbon oxidation in three continental margin sediments. Marine Geology 113, $27-40$.

Canfield, D.E, Thamdrup, B., Hansen, J.W., 1993. The anaerobic degradation of organic matter in Danish coastal sediments: $\mathrm{Fe}$ reduction, $\mathrm{Mn}$ reduction and sulfate reduction. Geochimica et Cosmochimica Acta 57, 2563-2570.

Capone, D.G., 2000. The marine microbial nitrogen cycle. In: Kirchman, D.L. (Ed.), Microbial Ecology of the Oceans. WileyLiss, New York, pp. 455-493.

Carpenter, E.J., 1983. Nitrogen fixation by marine Oscillatoria (Trichodesmium) in the world's oceans. In: Carpenter, E.J., Capone, D.G. (Eds.), Nitrogen in the Marine Environment. Academic Press, New York, NY, pp. 65-103.

Carpenter, E.J., Capone, D.G. (Eds.), 1983. Nitrogen in the Marine EnvironmentAcademic Press, New York, NY, pp. 1-900.

Christensen, J.P., 1994. Carbon export from continental shelves, denitrification and atmospheric carbon dioxide. Continental Shelf Research 14, 547-576.

Christensen, J.P., Rowe, G.T., 1984. Nitrification and oxygen consumption in northwest Atlantic deep-sea sediments. Journal of Marine Research 42, 1099-1116.

Christensen, J.P., Murray, J.W., Devol, A.H., Codispoti, L.A., 1987. Denitrification in continental shelf sediments has major impact on the oceanic nitrogen budget. Global Biogeochemical Cycles $1,97-116$.

Christensen, P.B., Rysgaard, S., Sloth, N.P., Dalsgaard, T., Schwærter, S., 2000. Sediment remineralization, nutrient fluxes, denitrification and dissimilatory nitrate reduction in an estuarine fjord with sea cage trout farms. Aquatic Microbial Ecology 21, $73-84$. 
Codispoti, L.A., 1989. Phosphorous versus nitrogen limitation of new and export production. In: Berger, W.H., Smetacek, V.S., Wefer, G. (Eds.), Productivity in the Ocean: Present and Past. Wiley, New York, pp. 377-394.

Codispoti, L.A., 1995. Is the ocean losing nitrate? Nature 376, 724.

Codispoti, L.A., Christensen, J.P., 1985. Nitrification, denitrification and nitrous oxide cycling in the eastern tropical south Pacific Ocean. Marine Chemistry 16, 277-300.

Codispoti, L.A., Brandes, J.A., Christensen, J.P., Devol, A.H., Naqvi, S.W.A., Paerl, H.W., Yoshinary, T., 2001. The oceanic fixed nitrogen and nitrous oxide budgets: moving targets as we enter the anthropocene? Sci. Mar. 65, 85-105.

Crutzen, P.J., 1970. The influence of nitrogen oxides on the atmospheric ozone content. Quarterly Journal of the Royal Meteorological Society 96, 320-325.

Cypionka, H., 1994. Sulfate transport. Methods in Enzymology 243, $3-14$.

Dalsgaard, T., Thamdrup, B., 2002. Factors controlling anaerobic ammonium oxidation with nitrite in marine sediments. Applied and Environmental Microbiology 68, 3802-3808.

Dalsgaard, T., Canfield, D.E., Petersen, J., Thamdrup, B., AcunaGonzález, J., 2003. $\mathrm{N}_{2}$ production by the anammox reaction in the anoxic water column of Golfo Dulce Costa Rica. Nature 422, 606-608.

Damsté, J.S.S., Strous, M., Rijpstra, W.I., Hopmans, E.C., Geenevasen, J.A.J., van Duin, A.C.T., van Niftrik, L.A., Jetten, M.S.M., 2002. Linearly concatenated cyclobutane lipids form a dense bacterial membrane. Nature 419, 708-712.

Davison, W., Grime, G.W., Morgan, J.A.W., Clarke, K., 1991. Distribution of dissolved iron in sediment pore waters at submillimetre resolution. Nature 352, 323-325.

Davison, W., Zhang, H., Grime, G.W., 1994. Performance characteristics of gel probes used for measuring the chemistry of pore waters. Environmental Science and Technology 28, $1623-1632$.

DeLong, E.F., 2002. All in the packing. Nature 419, 676-677.

Devol, A.H., 1991. Direct measurements of nitrogen gas fluxes from continental shelf sediments. Nature 349, 319-321.

Devol, A.H., 2003. Nitrogen cycle: solution to a marine mystery. Nature 422, 575-576.

Dhakar, S.P., Burdige, D.J., 1996. Coupled, non-linear, steady state model for early diagenetic processes in pelagic sediments. American Journal of Science 296, 296-330.

Dugdale, R., 1967. Nutrient limitation in the sea: dynamics, identification and significance. Limnology and Oceanography $12,685-695$.

Dugdale, R., Goering, J.J., 1967. Uptake of new and regenerated forms of nitrogen in primary productivity. Limnology and Oceanography 12, 196-206.

Emerson, S., Kalhorn, S., Jacobs, S., Tebo, B.M., Nealson, K., Rosson, R.A., 1982. Environmental oxidation rate of Mn(II): bacterial catalysis. Geochimica et Cosmochimica Acta 46, $1073-1079$.

Engström, P., Dalsgaard, T., Hulth, S., Aller, R.C., 2004. Anaerobic ammonium oxidation by nitrate: implicatons for $\mathrm{N}_{2}$ production in coastal marine sediments. Geochimica et Cosmochimica Acta (accepted for publication).
Eppley, R.W., Renger, E.H., Harrison, W.G., 1979. Nitrogen and phytoplankton production in southern Californian waters. Limnology and Oceanography 24, 483-494.

Falkowski, P.G., 1983. Enzymology of nitrogen assimilation. In: Carpenter, E.J., Capone, D.G. (Eds.), Nitrogen in the Marine Environment. Academic Press, New York, NY, pp. $839-868$.

Falkowski, P.G., 1997. Evolution of the nitrogen cycle and its influence on the biological sequestration of $\mathrm{CO}_{2}$ in the ocean. Nature 387, 272-275.

Falkowski, P.G., Barber, R.T., Smetacek, V., 1998. Biogeochemical controls and feedbacks on ocean primary production. Science 281, 200-206.

Fani, R., Gallo, R., Liò, P., 2000. Molecular evolution of nitrogen fixation: the evolutionary history of the nifD, $n i f K$, nifE, and nifN genes. Journal of Molecular Evolution $51,1-11$.

Finneran, K.T., Housewright, M.E., Lovley, D.R., 2002. Multiple influences of nitrate on uranium solubility during bioremediation of uranium-contaminated subsurface sediments. Environmental Microbiology 4, 510-516.

Fossing, H., Gallardo, V.A., Jørgensen, B.B., Hüttel, M., Nielsen, L.P., Schulz, H., Canfield, D.E., Forster, S., Glud, R.N., Gundersen, J.K., Küver, J., Ramsing, N.B., Teske, A., Thamdrup, B., Ulloa, O., 1995. Concentration and transport of nitrate by the mat-forming sulphur bacterium Thioploca. Nature $374,713-715$.

Froelich, P.N., Klinkenhammer, G.P., Bender, M.L., Luedtke, N.A., Heath, G.R., Cullen, D., Dauphin, P., Hammond, D., Hartman, B., Maynard, V., 1979. Early oxidation of organic matter in pelagic sediments of the eastern equatorial Atlantic: suboxic diagenesis. Geochimica et Cosmochimica Acta 43, $1075-1090$.

Gilbert, F., Souchu, P., Bianchi, M., Bonin, P., 1997. Influence of shell-farming activities on nitrification, nitrate reduction to ammonium and denitrification at the water - sediment interface of the Thau lagoon. Marine Ecology. Progress Series $151,143-153$.

Gilbert, F., Aller, R.C., Hulth, S., 2003. The influence of macrofaunal burrow spacing and diffusive scaling on sedimentary nitrification and denitrification: an experimental and model approach. Journal of Marine Research 61, 101-125.

Glud, R.N., Ramsing, N.B., Gundersen, J.K., Klimant, I., 1996. Planar optrodes: a new tool for fine scale measurements of two dimensional $\mathrm{O}_{2}$ distribution in benthic communities. Marine Ecology. Progress Series 140, 217-226.

Golet, D.S., Ward, B.B., 2001. Vertical distribution of denitrification potential, denitrifying bacteria, and benzoate utilization in intertidal microbial mat communities. Microbial Ecology 42, $22-34$.

Goloway, F., Bender, M., 1982. Diagenetic models of interstitial nitrate profiles in deep sea suboxic sediments. Limnology and Oceanography 27, 624-638.

Goreau, T.J., Kaplan, W.A., Wofsy, S.C., McElroy, M.B., Valois, F.W., Watson, S.W., 1980. Production of $\mathrm{NO}_{2}^{-}$and $\mathrm{N}_{2} \mathrm{O}$ by nitrifying bacteria at reduced concentrations of oxygen. Applied and Environmental Microbiology 40, 526-532. 
Gruber, N., Sarmiento, J.L., 1997. Global patterns of marine nitrogen fixation and denitrification. Global Biogeochemical Cycles 11, 235-266.

Gundersen, J.K., Jørgensen, B.B., 1990. Microstructure of diffusive boundary layers and the oxygen uptake of the sea floor. Nature $345,604-607$.

Habicht, K.S., Gade, M., Thamdrup, B., Berg, P., Canfield, D.E., 2002. Calibration of sulfate in the Archean ocean. Science 298, $2372-2374$

Hafenbradl, D., Keller, M., Dirmeier, R., Rachel, R., Rossnagel, P., Burggraf, S., Huber, H., Stetter, K.O., 1996. Ferroglobus placidus gen. nov., sp. nov., a novel hyperthermophilic archaeum that oxidizes $\mathrm{Fe}^{2+}$ at neutral $\mathrm{pH}$ under anoxic conditions. Archives of Microbiology 166, 308-314.

Hattori, A., 1983. Denitrification and dissimilatory nitrate reduction. In: Carpenter, E., Capone, D.B. (Eds.), Nitrogen in the Marine Environment. Academic Press, San Diego, pp. 191-232.

Hedges, J.I., Keil, R.G., 1995. Sedimentary organic matter preservation: an assessment and speculative synthesis. Marine Chemistry 49, 81-115.

Henriksen, K., Kemp, M., 1988. Nitrification in estuarine and coastal marine sediments. In: Blackburn, T.H., Sørensen, J. (Eds.), Nitrogen Cycling in Coastal Marine Environments. Wiley-Liss, New York, pp. 207-273.

Herbert, R.A., 1999. Nitrogen cycling in coastal marine ecosystems. FEMS Microbiology Reviews 23, 563-590.

Hesslein, R.H., 1976. An in situ sampler for close interval pore water studies. Limnology and Oceanography 21, 912-914.

Holland, H.D., 1994. Early Proterozoic atmospheric change. Bengtson, S. Early Life on Earth, Nobel Symposium vol. 84. Columbia University Press, New York, pp. 237-244.

Howarth, R.W., 1988. Nutrient limitation of net primary production in marine ecosystems. Annual Reviews of Ecology $19,89-110$.

Howarth, R.W., Marino, R., 1988. Nitrogen fixation in freshwater, estuarine, and marine ecosystems: 2. Biogeochemical controls. Limnology and Oceanography 33, 688-701.

Hulth, S., Aller, R.C., Gilbert, F., 1999. Coupled anoxic nitrification/manganese reduction in marine sediments. Geochimica et Cosmochimica Acta 63, 49-66.

Hulth, S., Engström, P., Selander, E., Aller, R.C., 2002. A pH plate fluorosensor for early diagenetic studies of marine sediments. Limnology and Oceanography 47, 212-220.

Jahnke, R.A., Emerson, S.R., Murray, J.W., 1982. A model of oxygen reduction, denitrification, and organic matter mineralization in marine sediments. Limnology and Oceanography 27, $610-623$

Jetten, M.S.M., Strous, M., van de Pas Schoonen, K.T., Schalk, J., van Dongen, U.G.J.M., van de Graaf, A.A., Logemann, S., Muyzer, G., van Loosdrecht, M.C.M., Kuenen, J.G., 1999. The anaerobic oxidation of ammonium. FEMS Microbiology Reviews 22, 421-437.

Jetten, M.S.M., Wagner, M., Fuerst, J., van Loosdrecht, M., Kuenen, G., Strous, M., 2001. Microbiology and application of the anaerobic ammonium oxidation (anammox) process. Environmental Biotechnology 12, 283-288.
Jørgensen, B.B., 1977. Distribution of colorless sulfur bacteria (Beggiatoa spp.) in a coastal marine sediment. Marine Biology $41,19-28$.

Jørgensen, B.B., Gallardo, V.A., 1999. Thioploka spp: filamentous sulfur bacteria with nitrate vacuoles. FEMS Microbiology, Ecology 28, 301-313.

Karlsson, K., Hulth, S., Rosenberg, R., Ringdahl, K., 2004. Experimental recolonization of Baltic Sea reduced sediments: survival of benthic macrofauna and faunal effects of $\mathrm{N}$ and $\mathrm{P}$ sediment fluxes, personal communication.

Kasting, J.F., 1990. Bolide impacts and the oxidation state of carbon in the Earth's early atmosphere. Origins of Life and Evolution of the Biosphere 20, 199-231.

Kasting, J.F., 1993. Earth's early atmosphere. Science 259, 920-926.

Kasting, J.F., Siefert, J.L., 2001. The nitrogen fix. Nature 412, $26-27$.

Kasting, J.F., Walker, J.C.G., 1981. Limits on oxygen concentration in the prebiotic atmosphere and the rate of abiotic fixation of nitrogen. Journal of Geophysical Research 86, 1147-1158.

Kasting, J.F., Pavlov, A.A., Siefert, J.L., 2001. A coupled ecosystem - climate model for predicting the methane concentration in the Archean atmosphere. Origins of Life and Evolution of the Biosphere 31, 271-285.

Kirchman, D.L. (Ed.), Microbial Ecology of the Oceans. WileyLiss, New York, pp. 1-542.

Kirchman, D.L., 2000. Uptake and regeneration of inorganic nutrients by marine heterotrophic bacteria. In: Kirchman, D.L. (Ed.), Microbial Ecology of the Oceans. Wiley-Liss, New York, pp. $261-288$.

Knowles, R., 1982. Denitrification. Microbiological Reviews 46, $43-70$.

Koike, I., Sørensen, J., 1988. Nitrate reduction and denitrification in marine sediments. In: Blackburn, T.H., Sørensen, J. (Eds.), Nitrogen Cycling in Coastal Marine Environments. Wiley-Liss, New York, pp. 251-273.

Kostka, J.E., Luther III, G.W., Nealson, K.H., 1995. Chemical and biological reduction of $\mathrm{Mn}(\mathrm{III})$-pyrophosphate complexes: potential importance of dissolved Mn (II) as an environmental oxidant. Geochimica et Cosmochimica Acta 59, 885-894.

Kristensen, E., Blackburn, T.H., 1987. The fate of organic carbon and nitrogen in experimental marine sediment systems: influence of bioturbation and anoxia. Journal of Marine Research 45, 231-257.

Kühl, M., Revsbech, N.P., 2001. Biogeochemical microsensors for boundary layer studies. In: Boudreau, B., Jørgensen, B.B. (Eds.), The Benthic Boundary Layer. Oxford University Press, pp. $180-210$.

Kuypers, M.M.M., Sliekers, A.O., Lavik, G., Schmid, M., Jørgensen, B.B., Kuenen, J.G., Damsté, J.S.S., Strous, M., Jetten, M.S.M., 2003. Anaerobix ammonium oxidation by anammox bacteria in the Black Sea. Nature 422, 608-611.

Lipschultz, F., Wofsy, S.C., Ward, B.B., Codispoti, L.A., Friederich, G., Elkins, J.W., 1990. Bacterial transformations of inorganic nitrogen in the oxygen-deficient waters of the Eastern Tropical South Pacific Ocean. Deep-Sea Research 37, $1513-1541$ 
Lomstein, E., Jensen, M.H., Sørensen, J., 1990. Intracellular $\mathrm{NH}_{4}^{+}$ and $\mathrm{NO}_{3}^{-}$pools associated with deposited phytoplankton in a marine sediment (Aarhus Bight; Denmark). Marine Ecology. Progress Series 61, 97-105.

Lovley, D.R., 1991. Dissimilatory Fe(III) and Mn(IV) reduction. Microbiological Reviews 55, 259-287.

Lovley, D.R., 1993. Dissimilatory metal reduction. Annual Review of Microbiology 47, 263-290.

Lovley, D.R., 2000. Fe(III)- and Mn(IV)-reducing prokaryotes. In: Dworkin, M., Falkow, S., Rosenberg, E., Schleifer, K.-H., Stackebrandt, E. (Eds.), The Prokaryotes, (3rd ed., release 3.2)Springer, New York. December.

Lovley, D.R., Phillips, E.J.P., 1986. Organic matter mineralization with reduction of ferric iron in anaerobic sediments. Applied and Environmental Microbiology 51, 683-689.

Luther, G.W., Popp III, J.I., 2002. Kinetics of the abiotic reduction of polymeric manganese dioxide by nitrite: an anaerobic nitrification reaction. Aquatic Geochemistry 8, 15-36.

Luther III, G.W., Nuzzio, D.B., Wu, J., 1994. Speciation of manganese in Chesapeake Bay waters by voltammetric methods. Analytica Chimica Acta 284, 473-480.

Luther III, G.W., Sundby, B., Lewis, B.L., Brendel, P.J., Silverberg, N., 1997. Interactions of manganese with the nitrogen cycle: alternative pathways to dinitrogen. Geochimica et Cosmochimica Acta 61, 4043-4052.

Luther III, G.W., Brendel, P.J., Lewis, B.L., Sundby, B., Lefrancois, L., Silverberg, N., Nuzzio, D., 1998. Oxygen, manganese, iron, iodide, and sulfate distributions in pore waters of marine sediments measured simultaneously with a solid state voltammetric microelectrode. Limnology and Oceanography 43, 325-333.

McCarthy, J.J., Carpenter, E.J., 1983. Nitrogen cycling in nearsurface waters of the open ocean. In: Carpenter, E.J., Capone, D.G. (Eds.), Nitrogen in the Marine Environment. Academic Press, New York, pp. 487-512.

McElroy, M.B., 1983. Marine biological controls on atmospheric $\mathrm{CO}_{2}$ and climate. Nature 302, 328-329.

Meyer, R.L., Kjaer, T., Revsbech, N.P., 2001. Use of $\mathrm{NO}_{\mathrm{x}}-$ microsensors to estimate the activity of sediment nitrification and $\mathrm{NO}_{x}$-consumption along an estaurine salinity, nitrate and light gradient. Aquatic Microbial Ecology 26, 181-193.

Middelburg, J.J., Soetaert, K., Herman, P.M., Heip, C.H.R., 1996. Denitrification in marine sediments: a model study. Global Biogeochemical Cycles 10, 661-673.

Molinder, A.M., Street, J.J., 1989. Decomposition of hydrazine in aqueous solutions. Journal of Environmental Quality 18, $483-487$.

Mulder, A., van de Graaf, A.A., Robertson, L.A., Kuenen, J.G., 1995. Anaerobic ammonium oxidation discovered in a denitrifying fluidized bed reactor. FEMS Microbiology, Ecology 16, $177-184$

Murray, J.W, Jannasch, H.W., Honjo, S., Anderson, R.F., Reeburgh, W.S., Top, Z., Friederich, G.E., Codispoti, L.A., Izdar, E., 1989. Unexpected changes in the oxic/anoxic interface in the Black Sea. Nature 338, 411-413.

Murray, J.W, Codispoti, L.A., Friederich, G.E., 1995. The suboxic zone in the Black Sea. In: Huang, C.P., O’Melia,
C.R., Morgan, J.J. (Eds.), Aquatic Chemistry: Interfacial and Interspecies Processes, ACS Advances in Chemistry Series, vol. 244, pp. $157-176$.

Naqvi, S.W.A., Noronha, R.J., Reddy, C.V.G., 1982. Denitrification in the Arabian Sea. Deep-Sea Research 29, 459-469.

Navarro-González, R., McKay, C.P., Mvondo, D.N., 2001. A possible nitrogen crisis for Archean life due to reduced nitrogen fixation by lightning. Nature 412, 61-64.

Nealson, K.H., Saffarini, D., 1994. Iron and manganese in anaerobic respiration, Environmental significance, physiology, and regulation. Annual Review of Microbiology 48, 311-343.

Nealson, K.H., Stahl, D.H., 1997. Micro organisms and biogeochemical cycles: what can we learn from stratified communities? In: Banfield, J.F., Nealson, K.H. (Eds.), Geomicrobiology: Interactions Between Microbes and Minerals, Reviews in Mineralogy, vol. 35, pp. 5-34.

Nielsen, L.P., 1992. Denitrificacion in sediments determined from nitrogen isotope pairing. FEMS Microbiology, Ecology 86, $357-362$.

Ottley, C.J., Davison, W., Edmunds, W.M., 1997. Chemical catalysis of nitrate reduction by iron(II). Geochimica et Cosmochimica Acta 61, 1819-1828.

Payne, W.J., 1976. Reduction of nitrogenous oxides by microorganisms. Bacteriological Reviews 37, 409-452.

Pearl, H.W., Zehr, J.P., 2000. Marine nitrogen fixation. In: Kirchman, D.L. (Ed.), Microbial Ecology of the Oceans. Wiley-Liss, New York, pp. 261-288.

Pelegri, S.P., Nielsen, L.P., Blackburn, T.H., 1994. Denitrification in estuarine sediment stimulated by the irrigation activity of the amphipod Corophium volutator. Marine Ecology. Progress Series 105, 285-290.

Peterson, B.J., Howarth, R.W., 1987. Sulfur, carbon and nitrogen isotopes used to trace organic matter flow in the salt-marsh estuaries of Sapelo Island, Georgia. Limnology and Oceanography $32,1195-1213$.

Postgate, J.R., 1982. The Fundamentals of Nitrogen Fixation. Cambridge University Press, London.

Redfield, A.C., 1958. The biological control of chemical factors in the environment. American Journal of Science 46, 205-221.

Revsbech, N.P., 1990. Combined use of the acetylene inhibition technique and microsensors for quantification of denitrification in sediments and biofilms. In: Revsbech, N.P., Sørensen, J. (Eds.), Denitrification in Soil and Sediment. Plenum Press, New York, pp. 259-275.

Revsbech, N.P., Jørgensen, B.B., Blackburn, T.H., 1980. Oxygen in the sea bottom measured with a micro electrode. Science 207, $1355-1356$.

Richards, F.A., 1965. Chemical observations in some anoxic, sulfide-bearing basins and fjords. Proceedings of the Second International Water Pollution Research Conference Tokyo 1964. Pergamon Press.

Risgaard-Petersen, N., 2003. Coupled nitrification-denitrification in autotrophic and heterotrophic estuarine sediments: on the influence of benthic microalgae. Limnology and Oceanography $48,93-105$.

Risgaard-Petersen, N., Nielsen, L.P., Rysgaard, S., Dalsgaard, T., Meyer, R.-L., 2003. Application of the isotope pairing technique 
in sediments where anammox and denitrification coexist. Limnology and Oceanography: Methods 1, 63-73.

Robertson, L.A., Dalsgaard, T., Revsbech, N.P., Kuenen, J.G., 1995. Confirmation of aerobic denitrification in batch cultures using gas-ghromatography and N-15 mass-spectrometry. FEMS Microbiology, Ecology 18, 113-119.

Rysgaard, S., Christensen, P.B., Nielsen, L.P., 1995. Seasonal variation in nitrification and denitrification in estuarine sediment colonized by benthic microalgae and bioturbating infauna. Marine Ecology. Progress Series 126, 111-121.

Ryther, J.H., Dunstan, W.N., 1971. Nitrogen, phosphorous and eutrophication in the coastal marine environment. Science 171, $1008-1013$.

Schidlowski, M.A., 1988. A 3800-million-year isotopic record of life from carbon in sedimentary rocks. Nature 333, 313-318.

Schramm, A., Larsen, L.H., Revsbech, N.P., Ramsing, N.B., Amann, R., Schlefer, K.H., 1996. Structure and function of a nitrifying biofilm as determined by in situ hybridisation and the use of microelectrodes. Applied and Environmental Microbiology 62, 4641-4647.

Schultz, H.D., Dahmke, A., Schinzel, T., Wallman, K., Zabel, M., 1994. Early diagenetic processes, fluxes and reaction rates in sediments of the South Atlantic. Geochimica et Cosmochimica Acta 58, 2041-2060.

Seitzinger, S.P., 1988. Denitrification in freshwater and coastal marine ecosystems: ecological and geochemical significance. Limnology and Oceanography 33, 702-724.

Shaw, T., Jahnke, R., Gieskes, J., 1990. Early diagenesis in differing depositional environments: the response of transition metals in pore water. Geochimica et Cosmochimica Acta 54, 1233-1246.

Shen, Y., Buick, R., Canfield, D.E., 2001. Isotopic evidence for microbial sulphate reduction in the early Archean era. Nature 410, $77-81$.

Sliekers, A.O., Derwort, N., Campos Gomez, J.L., Strous, M., Kuenen, J.G., Jetten, M.S.M., 2002. Completely autotrophic ammonium removal over nitrite in one reactor. Water Research $36,2475-2482$.

Sørensen, J., Jørgensen, K.S., Colley, S., Hydes, D.J., Thomson, J., Wilson, T.R.S., 1987. Depth localization of denitrification in deep-sea sediment from the Madeira Abyssal Plain. Limnology and Oceanography 32, 758-762.

Straub, K.L., Buchholz-Cleven, B.E.E., 1998. Enumeration and detection of anaerobic ferrous iron-oxidizing, nitrate-reducing bacteria from diverse European sediments. Applied and Environmental Microbiology 64, 4846-4856.

Straub, K.L., Benz, M., Schink, B., Widdel, F., 1996. Anaerobic, nitrate-dependent microbial oxidation of ferrous iron. Applied and Environmental Microbiology 62, 1458-1460.

Strömberg, N., Hulth, S., 2001. An ammonium selective fluorosensor based on the principles of coextraction. Analytica Chimica Acta 443, 215-225.

Strömberg, N., Hulth, S., 2003. A fluorescence ratiometric detection scheme for ammonium based on the solvent sensitive dye MC 540. Sensors and Actuators B 6910, 1-11.

Strous, M., 2001. Microbiology and application of the anaerobic ammoniumoxidation ('anammox') process. Current Opinion in Biotechnology 12, 283-288.
Strous, M., Fuerst, J.A., Kramer, E.H.M., Logemann, S., Muyzer, G., van de Pas, K.T., Webb, R., Kuenen, J.G., Jetten, M.S.M., 1999. Missing lithotroph identified as new planctomycete. Nature 400, 446-449.

Strous, M., Kuenen, J.G., Jetten, M.S.M., 1999. Key physiology of anaerobic ammonium oxidation. Applied and Environmental Microbiology 65, 3248-3250.

Sundbäck, K., Miles, A., 2000. Balance between denitrification and microalgal incorporation of nitrogen in microtidal sediments NE Kattegat. Aquatic Microbial Ecology 22, 291-300.

Sundbäck, K., Miles, A., Göranson, E., 2000. Nitrogen fluxes, denitrification and the role of microphytobenthos in microtidal shallow-water sediments: an annual study. Marine Ecology. Progress Series 200, 59-76.

Tebo, B.M., 1991. Manganese(II) oxidation in the suboxic zone of the Black Sea. Deep-Sea Research 38, 883-905.

Tebo, B.M., Ghiorse, W.C., van Waasbergen, L.G., Siering, P.L., Caspi, R., 1997. Bacterially mediated mineral formation: insights into manganese (II) oxidation from molecular genetic and biochemical studies. In: Banfield, J.F., Nealson, K.H. (Eds.), Geomicrobiology: Interactions Between Microbes and Minerals, Reviews in Mineralogy, vol. 35, pp. 225-266.

Thamdrup, B., 2000. Bacterial manganese and iron reduction in aquatic sediments. Advances in Microbial Ecology 16, 41-83.

Thamdrup, B., Dalsgaard, T., 2000. The fate of ammonium in anoxic manganese oxide-rich marine sediment. Geochimica et Cosmochimica Acta 64, 4157-4164.

Thamdrup, B., Dalsgaard, T., 2002. Production of $\mathrm{N}_{2}$ through anaerobic ammonium oxidation coupled to nitrate reduction in marine sediments. Applied and Environmental Microbiology 68, $1312-1318$.

Thamdrup, B., Glud, R.N., Hansen, J.W., 1994. Manganese oxidation and in situ manganese fluxes from a coastal sediment. Geochimica et Cosmochimica Acta 58, 2563-2570.

Ullman, W.J., Aller, R.C., 1985. The geochemistry of iodine in near-shore carbonate sediments. Geochimica et Cosmochimica Acta 49, 967-978.

Van Cappellen, P., Viollier, E., Roychoudhury, A., Clark, L., Ingall, E., Lowe, K., Dichristina, T., 1998. Biogeochemical cycles of manganese and iron at the oxic-anoxic transition of a stratified marine basin (Orca Basin, Gulf of Mexico). Environmental Science and Technology 32, 2931-2939.

Van de Graaf, A.A., Mulder, A., de Bruijn, P., Jetten, M.S.M., Robertsson, L.A., Kuenen, J.G., 1995. Anaerobic oxidation of ammonium is a biologically mediated process. Applied and Environmental Microbiology 61, 1246-1251.

Van de Graaf, A.A., de Bruijn, P., Robertsson, L.A., Jetten, M.S.M., Kuenen, J.G., 1996. Autotrophic growth of anaerobic ammonium-oxidizing micro-organisms in a fluidized bed reactor. Microbiology 142, 2187-2196.

Vanderborght, J., Billen, G., 1975. Vertical distribution of nitrate concentration in interstitial water of marine sediments with nitrification and denitrification. Limnology and Oceanography 20, 953-961.

Van Loosdrecht, M.C.M., Jetten, M.S.M., 1998. Microbiological conversions in nitrogen removal. Water Science and Technology $38,1-7$. 
Vitousek, P.M., Aber, J., Howarth, R.W., Likens, J.E., Matson, P.A., Schindler, D.W., Schlesinger, W.H., Tilman, G.G., 1997. Human alteration of the global nitrogen cycle: causes and consequences. Ecological Issues 1, 1-15.

Ward, B.B., 2000. Nitrification and the marine nitrogen cycle. In: Kirchman, D.L. (Ed.), Microbial Ecology of the Oceans. WileyLiss, New York, pp. 427-453.

Ward, B.B., 2003. Significance of anaerobic ammonium oxidation in the ocean. Trends in Microbiology 11, 408-410.

Wolfbeis, O.S., 1991. Fiber Optical Chemical Sensors and Biosensors vols. I and II. CRC Press, Boca Raton.

Wollast, R., 1991. The coastal organic carbon cycle: fluxes, sources and sinks. In: Mantoura, R., Martin, J.M., Wollast, R. (Eds.), Ocean Margin Processes in Global Change. John Wiley, New York, pp. 365-381.
Young, J.P.W., 1992. Phylogenetic classification of nitrogen-fixing organisms. In: Stacey, G., Evans, H.J., Burris, R.H. (Eds.), Biological Nitrogen Fixation. Chapman \& Hall, New York, pp. $43-86$.

Yung, Y.L., McElroy, M.C., 1979. Fixation of nitrogen in the prebiotic atmosphere. Science 203, 1002-1004.

Zahnle, K.J., 1986. Photochemistry of methane and the formation of hydrocyanic acid (HCN) in the Earth's early atmosphere. Journal of Geophysical Research 91, 2819-2834.

Zehr, J.P., Ward, B.B., 2002. Nitrogen cycling in the ocean: new perspectives on processes and paradigms. Applied and Environmental Microbiology 68, 1015-1024.

Zumft, W.G., 1997. Cell biology and molecular basis of denitrification. Microbiology and Molecular Ecology Reviews 61, 533-616. 